This PDF is a selection from a published volume from the National Bureau of Economic Research

Volume Title: Financial Sector Development in the Pacific Rim, East Asia Seminar on Economics, Volume 18

Volume Author/Editor: Takatoshi Ito and Andrew K. Rose, editors

Volume Publisher: University of Chicago Press

Volume ISBN: 0-226-38684-8

Volume URL: http://www.nber.org/books/ito_07-2

Conference Date: June 22-24, 2007

Publication Date: February 2009

Chapter Title: Consumer Credit Market in Korea since the Economic Crisis

Chapter Author: Chang-Gyun Park

Chapter URL: http://www.nber.org/chapters/c0410

Chapter pages in book: (161 - 196) 


\title{
Consumer Credit Market in Korea since the Economic Crisis
}

\author{
Chang-Gyun Park
}

\subsection{Introduction}

The purpose of the chapter is twofold. One is to document the chronology of rapid growth of household credit in Korea since the foreign exchange crisis in 1997. The other is to examine the development of the credit card crisis in 2003 and evaluate the adequacy of ensuing policy responses.

Rapid increase in household debt was primarily the result of a largescale deregulation and paradigm shift mainly driven by various efforts taken to restructure the entire financial sector after the foreign exchange crisis in 1997 . The new principle adapted by financial institutions after the financial deregulation was to put most emphasis on resource allocation based on market mechanism. Price signal replaced direction government intervention as the criterion in allocation of credit resources. It was a wellknown secret in the Korean financial market that household lending had been more profitable than corporate lending. Consequently, removal of government intervention coupled with a low interest rate resulted in expansion of the consumer credit market in an unprecedented pace. While one cannot deny the fact that allocation of credit resources based on price signal increased the efficiency of the economic system, recent economic history offers many examples of financial turmoil that were sparked by rapid accumulation of debts soon after deregulation of the financial sector without carefully revamping the regulatory framework. The deregulation of the financial industry in Korea after the foreign exchange crisis was not an exception in the sense that it was followed by a boom in the consumer credit market that eventually resulted in a violent crash landing.

Chang-Gyun Park is an assistant professor in the College of Business Administration at Chung-Ang University 
The most serious damage was done to the credit card market. Arrears soared up and the overdue rate reached almost 30 percent. Several credit card companies went bankrupt and were bailed out by the government or parent banks. A sharp increase in the number of credit delinquents in large part due to overdue credit card debts was accompanied by an increase in unemployment and depression of consumption expenditure among the delinquents. The havoc in the credit card market also caused social problems such as disintegration of family and suicides that invited serious concerns from the general public as well as the policy circle. We discuss the development of the credit card crisis with the presumption that it is a classic example of regulatory failure. We argue that with timely and proper regulatory actions, much of the difficulty inflicted by the credit card crisis would have been alleviated, if not averted.

The next section describes the development of the consumer credit market in Korea after the foreign exchange crisis in 1997. Section 5.3 examines the causes and consequences of fast increase in household debt. Section 5.4 focuses on the credit card crisis that occurred in 2003 and evaluates the adequacy of policy measures that were taken in response to changes in market condition. The conclusion follows.

\subsection{Household Debt in Korea after the Economic Crisis}

\subsubsection{Increase in Household Debt}

While showing a clear sign of stabilization recently, household debt in Korea has grown at a spectacular pace since the foreign exchange crisis in 1997. According to figure 5.1, the household debt market seems to have gone through three distinguished phases since 1997. The first phase covers the period between 1997 and 1999 when household debt went through a period of slump following the foreign exchange crisis and the subsequent recession induced by the most part by the high interest rate policy that the Korean government vigorously pursued to restore stability in the foreign exchange market. Household debt dropped by 13 percent in 1998 and had not recovered the precrisis level until 2000. Only after 2000, it gained momentum for rapid growth observed in the following three years that constituted the second phase. Outstanding stock of household debt increased by 120 percent from 2000 to 2002, while disposable income increased only by 15.5 percent. As a consequence, debt burden soared, and households' ability to repay considerably deteriorated. For example, the debt-toincome ratio sharply increased to 113.3 percent in 2002 , from just 63.8 percent in 1999, and the debt-to-asset ratio also rose by 11.7 percentage points from 40.1 in 1999 to 51.8 in 2002 (see figure 5.2). ${ }^{1}$

1. Debt-to-income ratio is defined as the ratio between total household debt and disposable income for households and private unincorporated enterprises. Debt-to-asset ratio is defined 


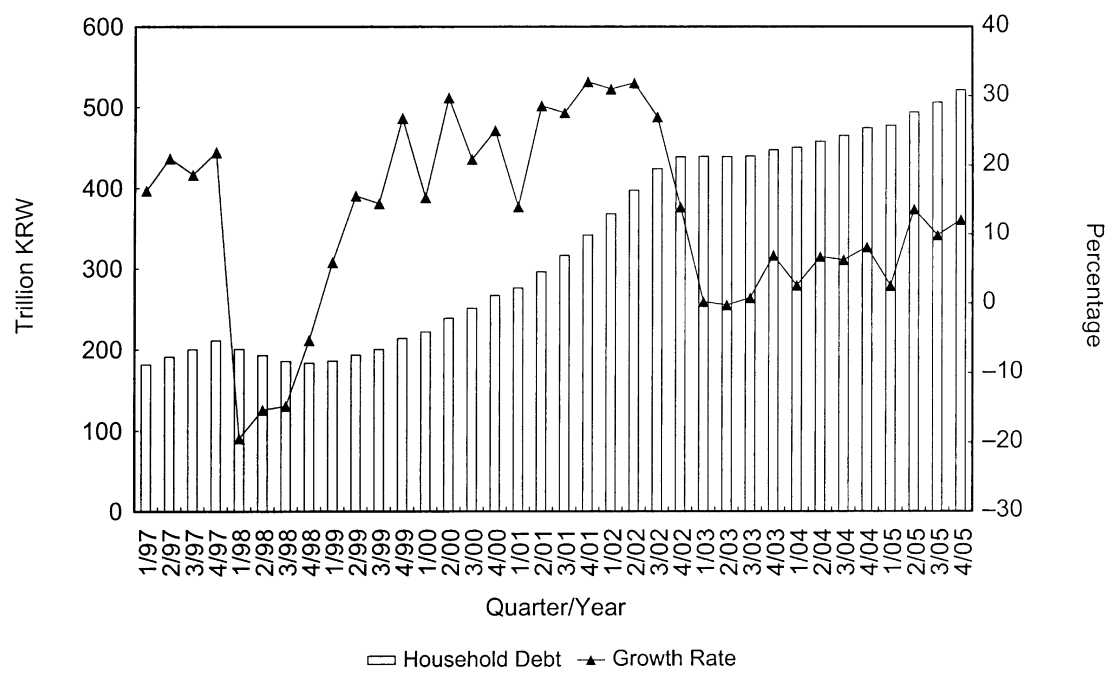

Fig. 5.1 Household debt in Korea: 1997-2005

Source: Bank of Korea.

Note: Growth rate is the annualized quarterly growth rate.

Rapid accumulation of household debt invited serious concerns from regulatory authority as well as credit providers. Alarmed with the unprecedented speed of debt accumulation, banks and credit card companies, two major credit providers to households, started to reconsider their business practices and tighten the conditions for credit provision. ${ }^{2}$ Regulatory authority also took various policy measures to curb the explosive growth of household debt. Consequently, the annual growth rate dropped to around 10 percent that is believed to be sustainable considering the long-term trend of aggregate income growth. However, the economy paid dear for rapid accumulation of household debt. The biggest credit card company in Korea was forced to resort to an emergency loan in order to avoid bankruptcy, and the financial market underwent a couple of turbulent episodes in 2003 and 2004. The third phase started in 2003. Seemingly uncontrollable accumulation of household debt came to a halt, and a cautious atmosphere replaced the feverish race to extend lending toward the household sector. While the speed of credit expansion was slowed down and the market regained a sense

as the ratio between total individual debt and total individual assets in the Flow of Funds table published by the Bank of Korea. The individual sector in the table includes private unincorporated enterprises and various nonprofit organizations as well as households. Therefore, household debt in figure 5.1 does not coincide with individual debt in the Flow of Funds table. The change of basis is unavoidable because information on aggregate asset holdings by households is not available.

2. Most of the credit providers, especially credit card companies, tried to increase market share in the belief that larger market share would bring them a competitive edge based on network effect. 


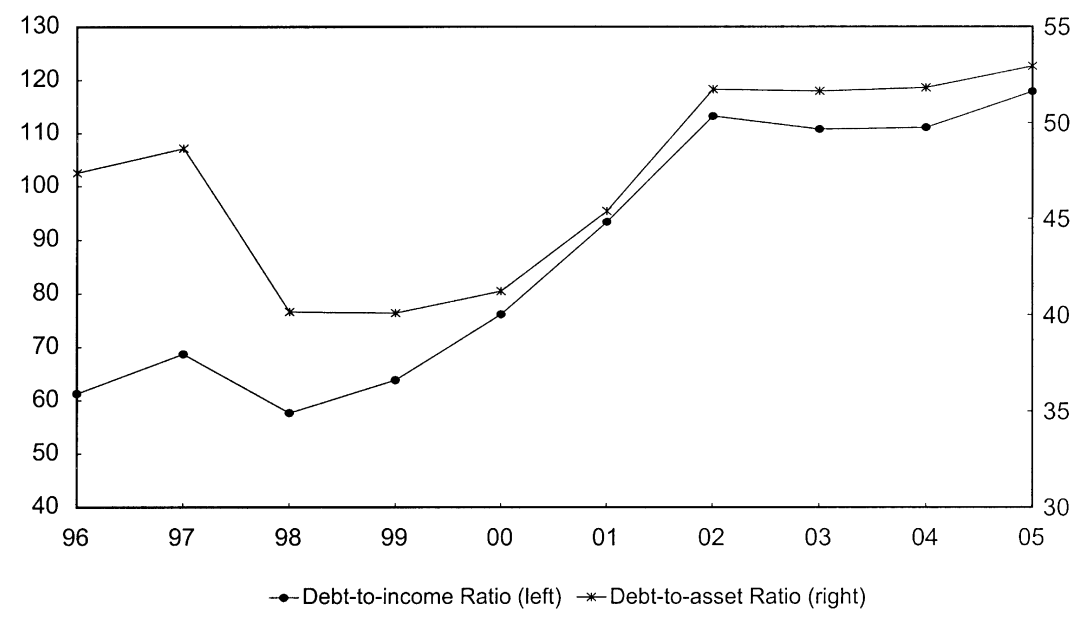

Fig. 5.2 Trend in ability-to-repay indicators

Source: Bank of Korea.

Notes: Debt-to-income ratio is the ratio between household debt and household disposable income. Debt-to-asset ratio is the ratio between individual debt and asset in the Flow of Funds table.

of stability, financial companies in the consumer credit market were forced to undergo a turbulent restructuring process to cope with serious degradation in quality of the consumer loan portfolios they possess.

\subsubsection{Household Debt by Lender Type}

\section{Banks}

Banks and credit card companies played the crucial role in increasing household debt. Banks were not the biggest lenders to the household sector until the second quarter of 1999 when the bank loans to the household sector overtook loans provided by other deposit taking institutions such as savings banks, credit unions, and mutual saving cooperatives (see figure 5.3). The increase in the bank's share in the consumer credit market from 1997 to 1999 was mainly due to contraction of nonbank deposit taking institutions. They were hit especially hard by the economic crisis in 1997 and subsequent restructuring of financial industry. Banks were also seriously affected by the economic crisis, but the outstanding stock of loans households borrowed from banks has steadily increased except for the second half of 1998 when the economy was in deep recession triggered by the economic crisis and high interest rate policy pursued by the Korean government. The status of banks as the biggest lender to the household sector was further solidified between 2000 and 2002, and 56.7 percent of total debt owed by the household sector was financed by banks in 2003 .

As shown in figure 5.4, the biggest share of bank loans to the household 


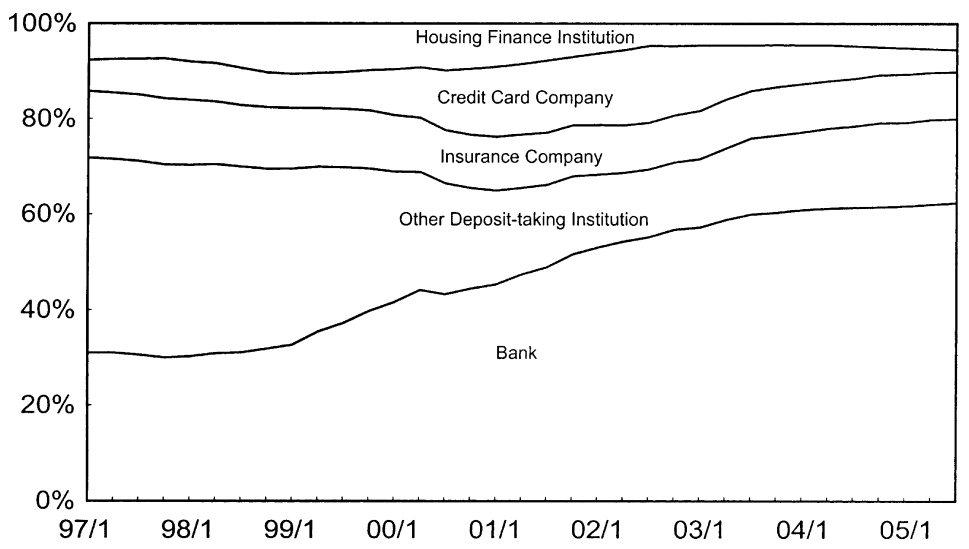

\section{Fig. 5.3 Household debt by lender type}

Source: Bank of Korea.

Notes: Housing finance institutions include the Korea Housing Finance Corporation and the National Housing Fund. Other deposit-taking institutions include savings banks, credit unions, and mutual saving cooperatives.

sector was taken up by loans to households secured by residential properties (LSRP). ${ }^{3}$ While the proportion of LSRP in total bank loans to the household sector was 47.8 percent at the end of 2000 , it had continuously risen to reach 62.4 percent in five years. During the five-year span from 2001 to 2005, a 71 percent increase in household debt provided by banks was attributable to an increase in LSRP. As discussed later, LSRP in Korea has very unique contract structure, and many commentators pointed out that the unique aspects of the loan contracts, especially short maturity and amortization scheme, could have some serious implications on the stability of the financial system.

\section{Credit Card Companies}

Another major contributor to the growth of consumer credit after the economic crisis in 1997 was credit card companies. The financial law in Korea allows financial institutions other than banks to issue credit cards and provide various supplementary services such as cash advances. ${ }^{4}$ Sensing a

3. Except for the National Housing Fund, the long-term mortgage market had not existed in Korea until the Korea Housing Finance Cooperation was established in 2004. Because the target of the National Housing Fund was limited to low- and middle-income households, most of the mortgage financing was intermediated through short-term bank loans collateralized by residential properties (LSRP). In Korea, LSRP has several distinguished features different from the traditional long-term mortgage product in terms of maturity, repayment method, loan decision criteria, and so on. It is called a bullet mortgage due to these special aspects of the loan contract. We discuss the details later.

4. In Korea, credit card companies are treated as financial institutions and are regulated by the financial regulator. The law regulating the industry is the "Credit-specialized financial company law." 


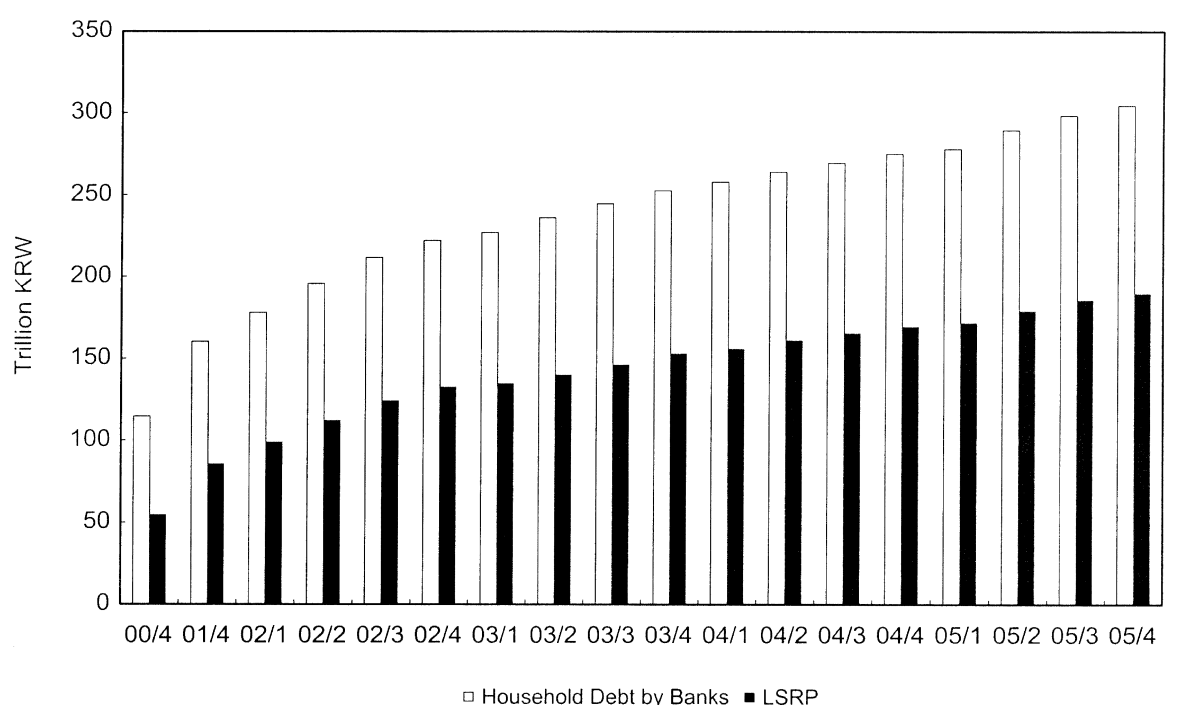

Fig. 5.4 Bank loans to household

Source: Bank of Korea.

Notes: LSRP is the loan to households secured by residential properties. Note that end-ofthe-year balances are presented for 2000 and 2001 due to lack of data.

lucrative profit opportunity in the consumer credit market, several big nonfinancial companies affiliated with big industrial conglomerates entered the credit card industry in the late 1980s, and banks also established credit card companies as an independent business to bypass restrictive regulations on the banking sector. ${ }^{5}$

Starting from 2000, credit card companies led the early stage in the expansion of consumer credit. Credit card debt increased by 270 percent, from 13.6 trillion Korea Won at the end of 1999 to 50.6 trillion KRW in the third quarter of 2002. Loans by credit card companies constituted only 8.4 percent of the total household debt at the end of 1999. However, the proportion of credit card debt doubled in three years, and it peaked at 16.2 percent in the third quarter of 2002. The explosive growth of credit card debt came to a sudden halt in the fourth quarter of 2002, mainly due to increasing concern of the sustainability of the credit card industry and various regulatory measures to restrain the expansion of credit card debt. Contraction of credit card debt stock was so spectacular that outstanding

5. Samsung Card and LG Card were two notable examples of big nonfinancial companies. Kookmin bank, the largest commercial bank in Korea and the Korea Exchange Bank were two examples of banks that established credit card companies. There were also banks that maintained a credit card business as an inside business unit. Most of the banks internalizing a credit card business participated in the market through a credit card association, BC Card. 


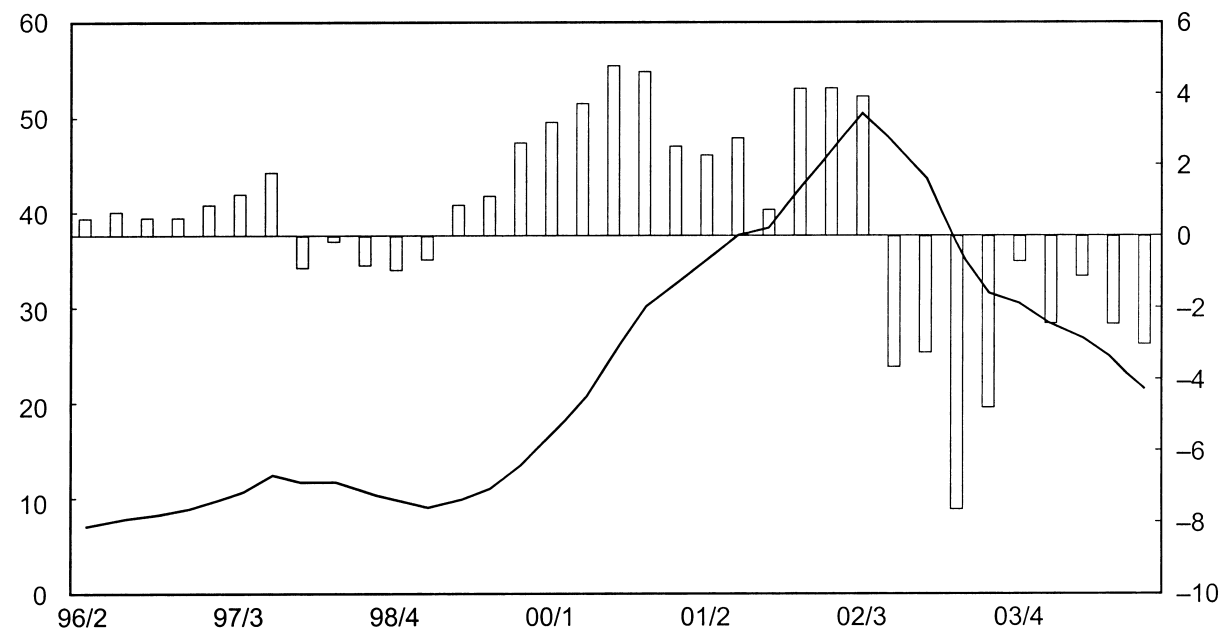

Fig. 5.5 Trend in credit card debt

Source: Financial Supervisory Service.

Notes: The bar chart indicates quarter-to-quarter change in outstanding balance and should be read by the scale on the right-hand side. Scale is in trillion Korean Won. The line graph indicates the outstanding balance at the end of each quarter and should be read by the scale on the left-hand side. Scale is in percentage.

debt stock reached 17.6 trillion KRW in the third quarter of 2005 (see figure 5.5). ${ }^{6}$

Credit cards typically provide three types of financial services to cardholders: full payment, installment, and cash advance services. Figure 5.6 illustrates the trend in the volume of transactions intermediated by the three categories of services. One noticeable feature we can point out from the figure is that the accumulation of credit card debt was primarily driven by cash advance services. ${ }^{7}$ It is widely accepted conventional wisdom in the credit card industry that the cash advance service is more vulnerable to credit risk than other forms of services. Loans initiated through cash advance should bring to borrowers high enough marginal utility that can justify a very high interest rate and consequently have much larger exposure to credit risks than other forms of services. During the period between 2000 and 2002, the transactions initiated by the cash advance service occupied more than half of total transactions intermediated by credit cards. That was an unmistakable foreboding of troublesome events to follow in two or three years.

6. That is, the size of outstanding credit card debt reduced by a third in three years.

7. We treat card loan as a form of cash advance service. 


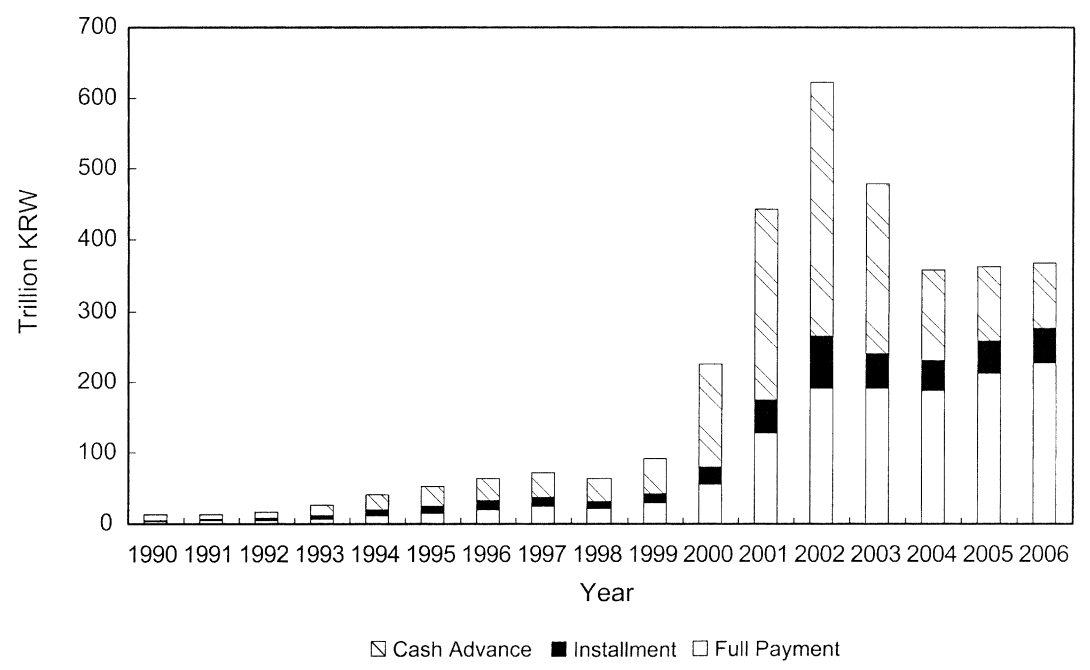

Fig. 5.6 Credit card transaction volumes by service type Source: Credit Finance Association of Korea.

\subsubsection{Distribution of Household Debt: Analysis of Microdata}

In this section, we briefly present a set of micro-level analyses in order to investigate the distributional aspects of increase in household debt. The Korea Labor Institute (KLI) has maintained a panel of representative households dating back to 1998. The annual survey, the Korea Labor and Income Panel Study (KLIPS), mainly focuses on labor-related issues, but it also provides information on various financial transactions. Among seven waves of surveys that are currently available for public use, we drop the first wave for compatibility reasons and employ data from 1998 to 2002 for the analyses. The time span covered by our data set coincides with the first and the second phases in the development of the consumer credit market after the economic crisis.

Table 5.1 reports the distribution of average debt holdings classified by the age of household head. The overall pattern generally conforms to the trend we observe in aggregate-level data. After a sluggish swing in 1998 and 1999, household debt started to increase at a considerable speed from 2000. Average debt holding per household increased by 40 percent from 17.3 million KRW in 1999 to 24.2 million in 2002. Even though household debt increased in all age groups, households with heads aged in their fifties experienced the fastest accumulation of debt. The average debt for the age group doubled between 1999 and 2002. Households whose heads were aged below thirty also experienced a significant jump in debt holdings. Their average debt increased by 75 percent during the same period. 
Table 5.1

Average household debt by age: 1998-2002 (thousand KRW)

\begin{tabular}{lcccccc}
\hline & \multicolumn{5}{c}{ Age group } & \\
\cline { 2 - 5 } Year & $\leq 29$ & $30-39$ & $40-49$ & $50-59$ & $60+$ & Total \\
\hline 1998 & 5,540 & 15,198 & 24,718 & 18,836 & 11,598 & 17,301 \\
1999 & 3,963 & 13,690 & 22,892 & 19,965 & 12,000 & 16,592 \\
2000 & 4,442 & 13,833 & 25,385 & 20,962 & 11,151 & 17,406 \\
2001 & 8,896 & 16,576 & 26,585 & 29,480 & 13,659 & 20,669 \\
2002 & 9,217 & 18,533 & 31,811 & 37,759 & 13,972 & 24,226 \\
\hline
\end{tabular}

Notes: Age group is classified by age of household head. The surveys were conducted from 1999 to 2003.

Table 5.2

Average household debt by income groups: 1998-2002 (thousand KRW)

\begin{tabular}{lrrrrr}
\hline Income percentile & 1998 & 1999 & 2000 & 2001 & 2002 \\
\hline $81-100$ & 44,210 & 39,730 & 33,724 & 35,200 & 41,316 \\
$61-80$ & 22,131 & 18,711 & 18,105 & 19,943 & 23,369 \\
$41-60$ & 12,934 & 13,057 & 15,544 & 14,831 & 17,035 \\
$21-40$ & 11,789 & 12,260 & 13,148 & 20,425 & 16,647 \\
$\leq 20$ & 8,808 & 7,853 & 9,686 & 6,793 & 9,760 \\
Total & 17,301 & 16,592 & 17,406 & 20,669 & 24,226 \\
\hline
\end{tabular}

Note: The surveys were conducted from 1999 to 2003.

Table 5.2 reports the average debt holdings by income percentiles. We can point out that low- and middle-income households experienced relatively faster growth of outstanding debt stock compared to the highincome group. Households belonging to the 21 percent to 40 percent income group saw their average debt balloon by 41 percent, from 11.8 million KRW in 1998 to 16.7 million KRW in 2002. Households belonging to the 41 percent to 60 percent income group also experienced significant increase in average debt holdings. However, it is interesting to note that debt holdings by the highest income group did not go through considerable fluctuations, and their average debt actually decreased differently from other income groups.

We can interpret the results in table 5.2 from two different perspectives. First of all, we can argue that the results provide indirect evidence for alleviation of credit constraints in the consumer credit market. The fact that lower-income households experienced faster debt accumulation may imply the alleviation of severe liquidity constraint placed on them under the practices prevailing in the financial market before the economic crisis. Before the economic crisis, direction intervention of the government in credit allocation was a common practice. The Korean government pursued the development policy to channel a disproportionately large amount of credit 
resources into a small group of targeted industries to promote faster growth. It was not rare that households were not able to borrow even though they did possess enough assets to offer as collateral in some cases, let alone borrowing without collateral. After the economic crisis in 1997, the Korean government gave up the traditional interventionist approach and let the market determine resource allocation in the credit market. It was then possible for financial institutions to increase the credit supply to the household sector with less concern about nonentrepreneurial factors.

While the increase of credit provision to the household sector can be used as evidence for lessening credit constraints, some critics pay particular attention to the fact that low-income households were provided credit in such a scale in such a short span of time. They argue that considering the speed and distributional feature of consumer credit expansion, it is quite difficult to justify without assuming some form of negligence from credit providers. Until recently, banks in Korea had relied on old-fashioned judgmental methods in credit evaluation and had not been equipped with formal credit risk management methods such as a credit scoring system. Moreover, credit card companies used to issue credit cards to consumers without proper checks on the ability to repay. They argue that the expansion of consumer credit after the economic crisis was at least partly attributable to an inadequate risk management system, and the seeds for turmoil in the Korean financial market in 2003 and 2004 had already started to germinate.

We can also find evidence for the mounting debt burden on households in microdata. Figure 5.7 summarizes change in average debt service ratio (DSR) from 1998 to $2004 .{ }^{8}$ The DSR reported in figure 5.7 was calculated based on the Survey of Household Income and Expenditure (SHIE), an annual survey by the Korea National Statistical Office. The SHIE provides vast amounts of detailed information on household expenditure and income that the KLIPS does not report. The proportion of income dedicated to pay interest and principals, if not rolled over, had been consistently increased from 13.04 percent in 1998 to 22.97 percent in 2004. Even under a persistently low interest rate and generous rollover policy, repayment burden measured in DSR almost doubled in just six years. Low-income families were affected more by increased debt burden than high-income families, which is in line with the result in table 5.2, where low-income families were the main beneficiaries of extended credit opportunities.

In order to investigate the distributional aspects of debt accumulation by households in a more formal manner, we estimate the following empirical model with KLIPS panel data;

8. Debt service ratio is defined as the ratio between the amounts used to pay interest and principal, if any, to income. 


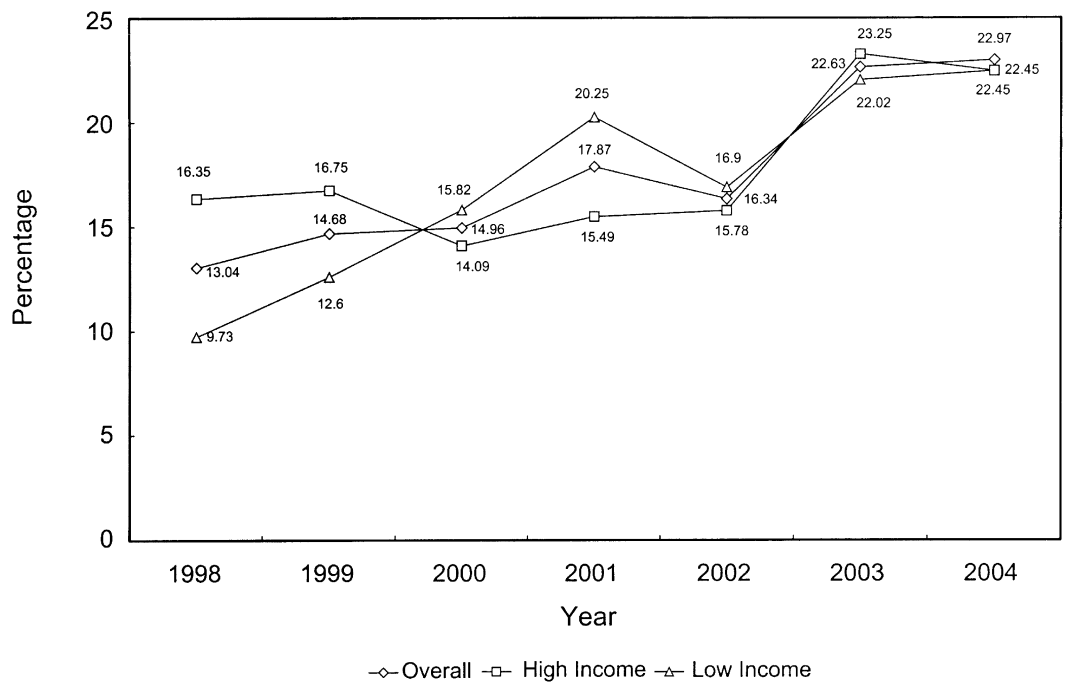

\section{Fig. 5.7 Debt service ratio}

Notes: High (low) income indicates the average DSR of households belonging to upper (lower) 50 percent of income distribution. All figures are in percentiles.

$$
y_{i y}^{*} 1_{\left[y_{i t}^{*}>0\right]}=\beta^{\prime} \mathbf{x}_{i t}+\mu_{i}+\varepsilon_{i t}
$$

where $y_{i t}^{*}$ is the difference between supply of debt and desired level by household $i, \mathbf{x}_{i t}$ is a vector of explanatory variables, $\mu_{i}$ is the individual fixed effect, and $\varepsilon_{i t}$ is error term. ${ }^{9}$ Econometricians are able to observe the amount of debt held by a household only if the desired level is lower than the level to which lenders are willing to provide credit. We have a fixed effect panel specification with a censored dependent variable and estimate the model using a trimmed least squares (TLS) estimator proposed by Honoré (1992) after imposing the usual independently and identically distributed (i.i.d.) normality assumption on the error term. ${ }^{10}$ The explanatory variables included in the regression are all frequently cited variables in the literature. ${ }^{11}$ Income, amount of asset holding, family size, dummies for household head's age, educational attainment, homeownership, and a dummy for type of employment are included. The estimation result is reported in table 5.3.

The estimation result conforms to previous research done in other countries. ${ }^{12}$ Income, asset holding, family size, education attainment, and

9. For a theoretical background of the empirical model, see Crook (2001).

10. Precisely speaking, the estimator is $\hat{\beta}_{4}$ in the original paper, and it is obtained by optimizing the loss function defined as $T_{n}(b)$.

11. See Bertola, Disney, and Grant (2006).

12. See Crook (2006). 
Table 5.3

Determinants of debt holdings

\begin{tabular}{|c|c|c|c|c|}
\hline & Model I & Model II & Model III & Model IV \\
\hline Income & $\begin{array}{l}0.2106^{* * *} \\
(0.0219)\end{array}$ & $\begin{array}{c}0.2134 * * * \\
(0.02194)\end{array}$ & $\begin{array}{l}0.2167^{* * *} \\
(0.0218)\end{array}$ & $\begin{array}{c}-0.4299 * * * \\
(0.1140)\end{array}$ \\
\hline Income squared & & & & $\begin{array}{l}0.0471 * * * \\
(0.0081)\end{array}$ \\
\hline Net asset & $\begin{array}{l}0.0793 * * * \\
(0.0096)\end{array}$ & $\begin{array}{l}0.0776 * * * \\
(0.0096)\end{array}$ & $\begin{array}{l}0.0453^{* * *} \\
(0.0100)\end{array}$ & $\begin{array}{l}0.0471 * * * \\
(0.0100)\end{array}$ \\
\hline Family size & $\begin{array}{l}0.0933^{* * *} \\
(0.0189)\end{array}$ & $\begin{array}{l}0.0892 * * * \\
(0.0188)\end{array}$ & $\begin{array}{l}0.0841^{* * *} \\
(0.0187)\end{array}$ & $\begin{array}{l}0.0785^{* * * *} \\
(0.0186)\end{array}$ \\
\hline Marriage $($ married $=1)$ & $\begin{array}{c}0.0071 \\
(0.1235)\end{array}$ & $\begin{array}{c}0.0082 \\
(0.1229)\end{array}$ & $\begin{array}{c}0.0151 \\
(0.1218)\end{array}$ & $\begin{array}{c}0.0183 \\
(0.1212)\end{array}$ \\
\hline Education 1 (high school = 1) & $\begin{array}{l}0.2196^{* * * *} \\
(0.0668)\end{array}$ & $\begin{array}{l}0.2176^{* * * *} \\
(0.0663)\end{array}$ & $\begin{array}{l}0.2269^{* * *} \\
(0.0658)\end{array}$ & $\begin{array}{l}0.2111^{* * * *} \\
(0.0655)\end{array}$ \\
\hline Education $2($ college $=1)$ & $\begin{array}{l}0.2522 * * * \\
(0.0534)\end{array}$ & $\begin{array}{l}0.2841 * * * \\
(0.0533)\end{array}$ & $\begin{array}{l}0.2959 * * * \\
(0.0529)\end{array}$ & $\begin{array}{l}0.2639 * * * \\
(0.0529)\end{array}$ \\
\hline Age $1(35 \leq$ age $<45)$ & $\begin{array}{l}0.2015^{* * *} \\
(0.0663)\end{array}$ & $\begin{array}{l}0.1698 * * * \\
(0.0626)\end{array}$ & $\begin{array}{l}0.1396^{* *} \\
(0.0678)\end{array}$ & $\begin{array}{l}0.1320^{* * * *} \\
(0.0667)\end{array}$ \\
\hline Age $2(45 \leq$ age $<55)$ & $\begin{array}{c}0.4247 \\
(1.4157)\end{array}$ & $\begin{array}{c}0.3694 \\
(1.3682)\end{array}$ & $\begin{array}{c}0.2982 \\
(0.9320)\end{array}$ & $\begin{array}{c}0.2818 \\
(1.0437)\end{array}$ \\
\hline Age $3(55 \leq$ age $<65)$ & $\begin{array}{c}0.5305^{*} \\
(0.3031)\end{array}$ & $\begin{array}{c}0.4698 * \\
(0.2847)\end{array}$ & $\begin{array}{c}0.3870 \\
(0.2513)\end{array}$ & $\begin{array}{c}0.3699 \\
(0.2531)\end{array}$ \\
\hline Age $4(65 \leq$ age $)$ & $\begin{array}{l}0.2111^{* * *} \\
(0.0198)\end{array}$ & $\begin{array}{l}0.1416^{* * *} \\
(0.0578)\end{array}$ & $\begin{array}{l}0.0417^{* * *} \\
(0.0151)\end{array}$ & $\begin{array}{l}0.0004^{* * * *} \\
(0.0001)\end{array}$ \\
\hline Type of employment (self employed $=1$ ) & & $\begin{array}{l}0.3224 * * * \\
(0.0455)\end{array}$ & $\begin{array}{l}0.3383 * * * \\
(0.0452)\end{array}$ & $\begin{array}{l}0.332 * * * \\
(0.0450)\end{array}$ \\
\hline Unemployed (unemployed = 1) & & $\begin{array}{c}-0.1139 * * \\
(0.0558)\end{array}$ & $\begin{array}{r}-0.1053^{*} \\
(.00553)\end{array}$ & $\begin{array}{c}-0.1021^{* *} \\
(0.0552)\end{array}$ \\
\hline Homeownership (homeowner $=1$ ) & & & $\begin{array}{l}0.3571 * * * \\
(0.0335)\end{array}$ & $\begin{array}{l}0.3554 * * * \\
(0.0436)\end{array}$ \\
\hline $\begin{array}{l}\text { No. of observations } \\
\text { Wald }\end{array}$ & $\begin{array}{c}6,114 \\
615.07 * * * \\
(10)\end{array}$ & $\begin{array}{c}6,114 \\
672.49 * * * \\
(12)\end{array}$ & $\begin{array}{c}6,114 \\
793.27^{* * *} \\
(13)\end{array}$ & $\begin{array}{c}6,114 \\
833.27^{* * *} \\
(14)\end{array}$ \\
\hline
\end{tabular}

Notes: The dependent variable is in log and income; net asset are also in log. Quadratic loss function is minimized for fixed effect Tobit model as suggested by Honoré (1992). Standard errors are in parentheses. The Wald statistic is the test statistic for the joint significance of all explanatory variables except for the intercept. Degrees of freedom are in parentheses under the test statistics.

***Significant at the 1 percent level.

**Significant at the 5 percent level.

*Significant at the 10 percent level.

homeownership are all significantly and positively related to debt holding. On the other hand, wage earners and the unemployed are likely to hold smaller debt stocks. Other sociodemographic variables such as marriage and sex do not seem to be important factors in the determination of household demand for debt. Income elasticity of debt demand is consistently estimated to be around 0.2 , which is much larger than (net) asset elasticity of debt demand. Unlike the findings for other countries in Crook (2006) that 
reports a concave function of income, demand for debt holding is a convex function of income in the data range.

The pattern of debt accumulation along the life cycle closely follows that of income, increasing in the thirties and forties and reaching the maximum at midfifties then decreasing afterward. The pattern is quite different from those typically found in other countries.

In most of the countries reported in Crook (2006), demand for debt decreases as the age of household head increases. However, in the Korean case, households accumulate more debts as age increases until reaching retirement age. Such a pattern may reflect the characteristic feature of the housing finance market in Korea. In the absence of a well-functioning long-term mortgage market, a typical family in Korea has to accumulate financial assets until savings can cover the down payment required to purchase a home, which is, in most cases, at least 40 percent of the housing price. The remaining amount should be borrowed from financial institutions, mainly banks, by offering the house for collateral. Therefore, the average age of a first-time home buyer in Korea is higher than that in other countries where a long-term mortgage market is well established. Because most home purchases are related to debt increase to some degree, as shown in a significantly positive correlation between debt and homeownership in table 5.3, the pattern of debt accumulation is likely to be closely correlated with that of home purchase and mortgage debt repayment. People start to buy homes in their late thirties, and the number of first-time home buyers peaks at the midforties. Moreover, because most mortgage debts are not amortized under the convention that debts are rolled over when maturities arrive, we do not observe a statistically significant drop in debt holdings even after home purchases.

\subsection{Causes and Consequences}

\subsubsection{Causes}

\section{Changes in the Financial Market Environment}

One of most obvious reasons why household debt increased at such a remarkable speed in Korea seemed to be the low interest rate environment that started in 1999 as the Korean government gave up the high interest policy.

The policy especially advocated by the International Monetary Fund was taken to restore stability in the foreign exchange market. Confronted with a severe recession in 1998 due to a high interest rate and positive signs in the foreign exchange market stability, the Korean government lowered the interest rate to stimulate the slumping economy. In line with the favorable condition in the global financial market, the low interest rate policy has been retained thereafter as shown in figure 5.8. Because a low interest 


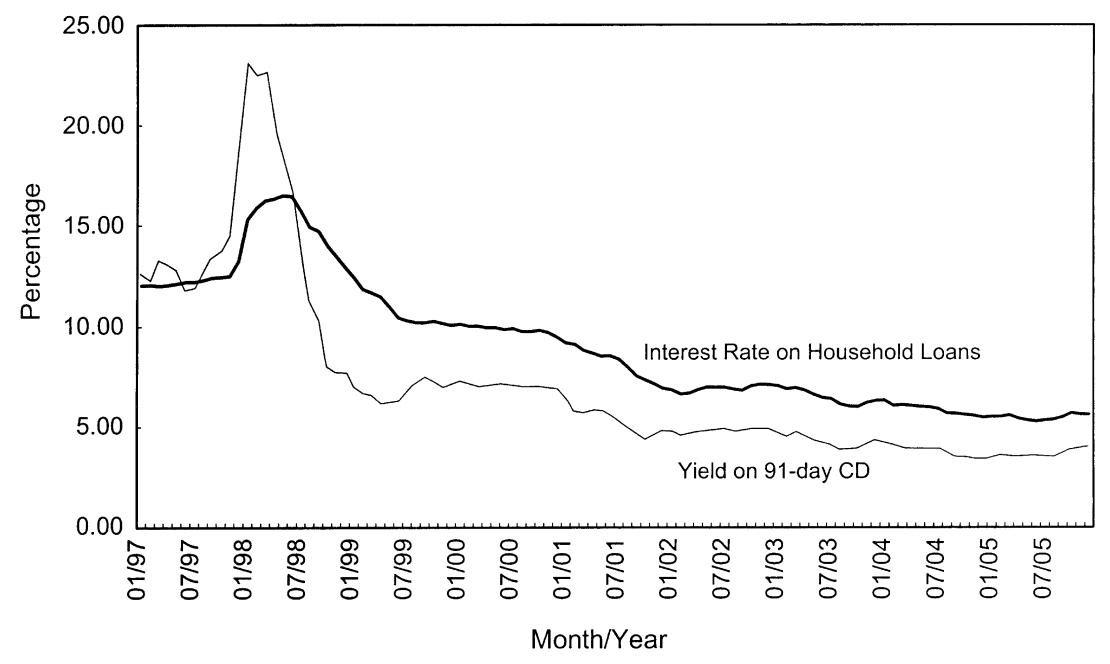

Fig. 5.8 Interest rates: 1997-2005

Source: Bank of Korea.

rate, ceteris paribus, implies lower cost for debt financing and stronger demand for borrowing, the low interest rate must have significantly contributed to rapid increase in household debt.

Another fundamental change in the financial market was the change in the financing pattern of the corporate sector. Before the economic crisis, the Korean government chose the strategy to pursue economic development by utilizing large conglomerates, chaebols, as the main engine. The government mobilized massive amounts of credit resources required for large-scale investment through the banking sector. Bank loans rather than bonds or equities had been the main financial vehicles through which the corporate sector raised funds for investment. However, the structural fragility of the debt-driven development strategy was clearly revealed when the economy was hit hard by sudden and massive capital outflow as the solvency of chaebols became suspicious. Many conglomerates were forced to declare bankruptcy or resort to a restructuring procedure. Several commercial banks suffered severe losses from large nonperforming loans concentrated on failing conglomerates and were taken over by the Korea Deposit Insurance Corporation or other less-affected banks to prevent a collapse of the financial system. Out of thirty-three commercial banks operating at the end of 1997, ten banks disappeared. Five were liquidated, and the other five were acquired by other surviving banks. Once the financial system regained stability, the Korean government accepted the reality that pursuing economic development by channeling bank credits to selected sectors was no longer viable and required the corporate sector to strengthen the financial structure by reducing debt and injecting more cap- 
ital. As a result, the focus of funding for corporate investment shifted from the banking sector to the capital market.

Table 5.4 illustrates the inflow of funds to the corporate sector from banks and the capital market. We can confirm the fact that the capital market replaced the banking sector as the main funding source for the corporate sector after the economic crisis. Shrinking demand for bank loans from the corporate sector naturally put pressure on banks to pursue a more aggressive approach in promoting loans to the household sector.

The structural transformation of banks' loan portfolios is clearly illustrated in figure 5.9. The proportion of household loans in banks' total loan portfolios had stayed well below 30 percent until 1998 but increased continuously to reach 48.9 percent in 2004. In 2005, hitting the historical high

Table 5.4

Source of corporate finance (billion KRW)

\begin{tabular}{lrrr}
\hline Year & Bank loan & Bond and equity & Total \\
\hline 1996 & 44,977 & 35,191 & 80,167 \\
1997 & 37,728 & 37,731 & 75,459 \\
1998 & $-63,634$ & 70,253 & 6,619 \\
1999 & $-3,759$ & 71,785 & 68,026 \\
2000 & 19,658 & 73,011 & 92,669 \\
2001 & $-27,487$ & 99,363 & 71,875 \\
2002 & 34,002 & 87,421 & 121,423 \\
2003 & 28,129 & 72,909 & 101,038 \\
\hline
\end{tabular}

Source: Bank of Korea.

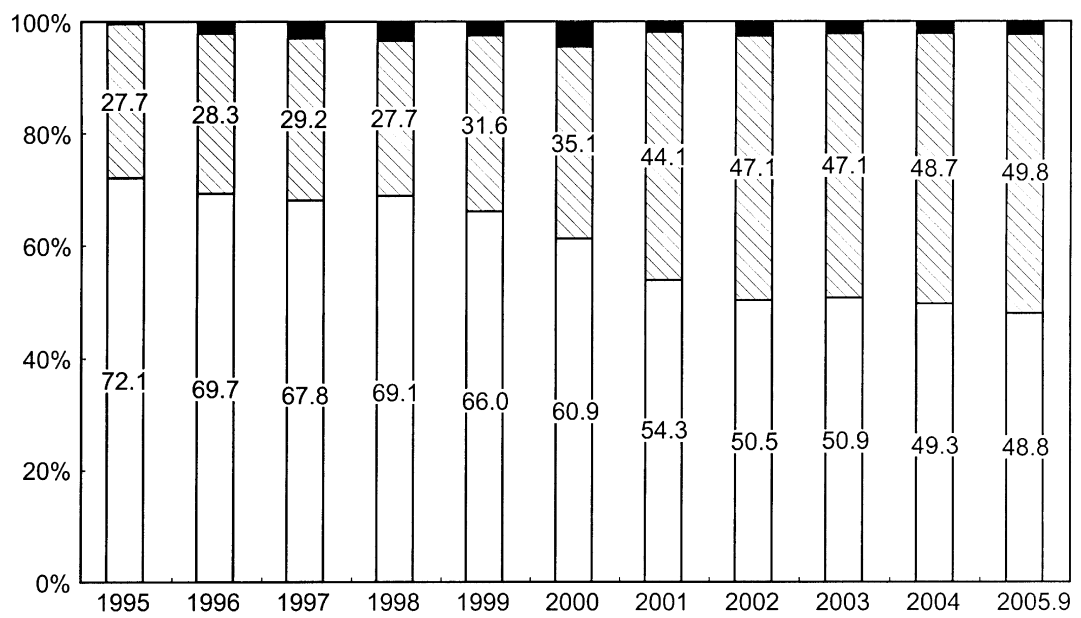

Fig. 5.9 Composition of banks' loan portfolios

Source: Bank of Korea.

Note: From bottom to top, household loans, corporate loans, and others. 
at 49.8 percent, loans to the household sector finally surpassed those to the corporate sector.

\section{Deregulation of the Financial Sector}

Though deregulation of the financial sector had already begun in the 1990s, it was not until the onset of the economic crisis in 1997 that the liberalization and deregulation of the financial market was vigorously pursued. Amid various policies and actions taken during the deregulation process, the most important change was the paradigm shift in the way financial institutions are managed. Under the old regime, banks were simply regarded as instrumental agents to mobilize savings and channel them to strategically selected industries. Profitability of individual banks was not a primary concern as long as banks served the policy goals set by the government. Even banks themselves did not regard themselves as private businesses but as semipublic entities with an important mission to serve the public interest by contributing to economic development. Under the new regime, the government gave up the traditional approach to the financial sector as well as to economic development. Enhancement of the efficiency in the allocation of credit resources became the primary policy goal of financial regulation, and price mechanism replaced the government as the main player in credit resource allocation.

Aside from the fundamental paradigm shift in financial regulation, numerous measures were taken to embody the philosophical transformation at the operational level. The entry barrier to the financial industry was lowered significantly, and foreigners were allowed enter the industry by establishing a local subsidiary or acquiring the existing domestic companies. The Financial Holding Company Act was enacted to promote competition among different sectors in the financial industry. Implicit regulation on the interest rate and service fees on financial services were also abolished, and financial institutions were given discretion to choose the level of prices for the services they provide. Financial companies were allowed to be involved in numerous activities that had required authorization or consent from the regulator by simply reporting to the regulator.

As a result of fundamental changes brought by deregulation efforts, profitability was firmly established as the primary goal of all sorts of financial companies. Banks converted their attention to loans to the household sector from corporate loans they had consistently focused on. Except for intervention by the government, implicit or explicit, it is quite difficult to find justification for the large share of corporate loans before the economic crisis as shown in figure 5.9, considering the fact that loans to the household sector had consistently been, on average, more lucrative and less risky than loans to the corporate sector, at least until 2003 according to table 5.5. It was then natural in some sense to observe a sudden shift of business practice in the banking industry and fast growth of loans to the household sector. 


\begin{tabular}{lcccccc}
\hline & \multicolumn{2}{c}{ Loan rate } & & \multicolumn{3}{c}{ Default rate } \\
\cline { 2 - 3 } \cline { 6 - 7 } Year & Household & Corporate & & Household & Credit card & Corporate \\
\hline 1997 & 12.30 & 11.75 & & 3.3 & 3.3 & 7.3 \\
1998 & 15.21 & 15.20 & & 7.1 & 17.9 & 8.9 \\
1999 & 10.85 & 8.91 & & 3.2 & 6.8 & 4.4 \\
2000 & 9.88 & 8.18 & & 2.4 & 7.7 & 3.4 \\
2001 & 8.20 & 7.49 & & 1.3 & 7.5 & 2.1 \\
2002 & 6.92 & 6.50 & & 1.5 & 11.9 & 2.0 \\
2003 & 6.50 & 6.17 & & 1.8 & 10.9 & 2.1 \\
2004 & 5.88 & 5.92 & & 1.8 & 5.5 & 2.1 \\
2005 & 5.64 & 5.75 & & 1.4 & 3.9 & 1.9 \\
\hline
\end{tabular}

Notes: All interest rates are average rates charged for new loans in each category. Default rate of credit card loan is for all credit card debt granted by banks.

\subsubsection{Consequences}

\section{Efficiency Improvement and Welfare Gain}

Because wider penetration of financial intermediation offers more opportunities for mutually beneficial voluntary exchanges, it, in general, results in more efficient resource allocation and higher welfare. Even if it is difficult to draw a firm conclusion due to a lack of hard evidence, we can offer some circumstantial evidence for the claim that the increase in household debt may have brought several positive effects. Based on the discussion in the previous section, one can argue that increased inflow of credit resources into the household sector itself reflects efficiency improvement in the allocation of credit resources. Free from government intervention, lending financial institutions were able to take the full advantage of benefits from loans to the household sector, the higher interest rate, and the lower default rate. Borrowers also benefited from a more-generous provision of credit resources. As more and more consumers free themselves from credit and liquidity constraints, it became easier for them to achieve intertemporal reallocation of consumption in pursuing a smoother lifetime consumption path. According to an extensive study by Kim (1995), the household sector had been under very severe credit and liquidity constraints before the economic crisis, and it was virtually impossible to borrow from banks without providing collateral. ${ }^{13}$ At least to some degree, one cannot deny the fact that the large inflow of credit into the household sec-

13. Here is paradoxical evidence for the claim that consumer loans were severely discouraged. Two special purpose banks specializing in consumer credit were established by the government. Kookmin Bank, now privatized and the biggest commercial bank in Korea, was established to deal with the consumer and small office/home office (SOHO) loans. Another bank specializing in consumer finance was the Korea Housing Bank, merged with Kookmin Bank in 2001, whose business area was in mortgage finance. 


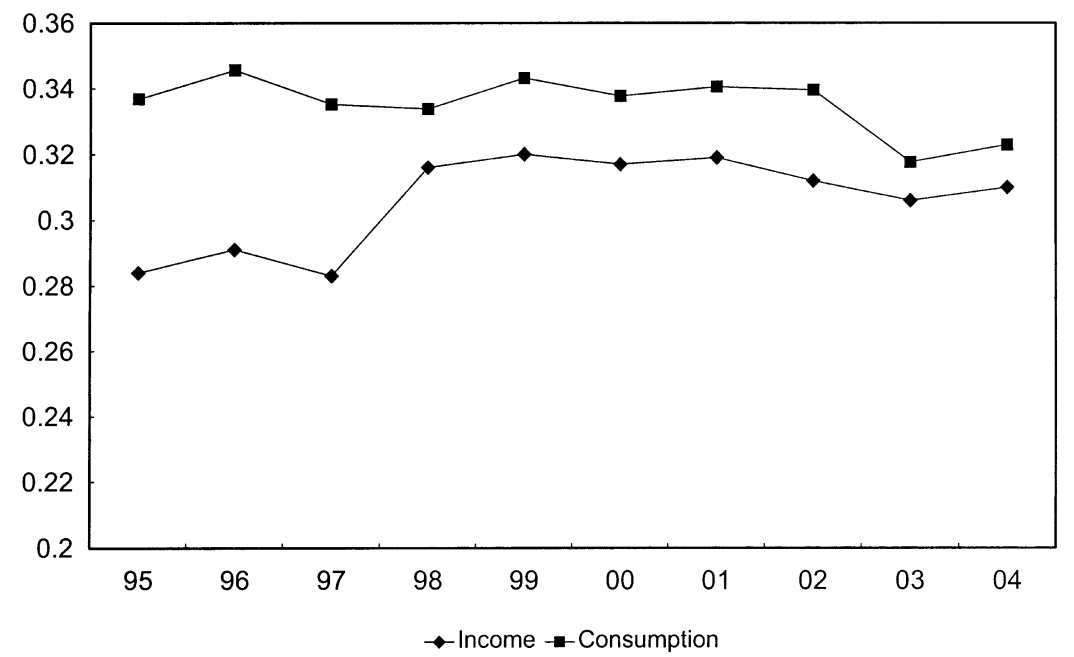

Fig. 5.10 Trend in Gini coefficient: Income and consumption

Source: Author's calculation based on the National Household Income and Expenditure Survey (NHIES).

tor contributed to alleviating restrictions imposed on intertemporal budget constraints and helped consumers achieve better resource allocation.

According to figure 5.10, while income distribution in Korea shows the tendency to worse as indicated by the rising Gini coefficient for income distribution after the economic crisis, inequality in consumption seems to be reduced. As long as the improvement in consumption equality was not totally financed by reckless loan provision by lenders who did not recognize the importance of credit evaluation in making a loan decision, this could imply that fewer consumers are affected by imperfection in the financial market and are able to attain a better position in allocating consumption in an intertemporal context. ${ }^{14}$

\section{Potential Deterioration of Stability in the Financial System}

In the previous section, we show that one of the main driving forces behind the explosive growth of household debt between 2000 and 2002 was the increase in LSRP supplied by banks. ${ }^{15}$ In the five years from 1999 to 2003, LSRP quadrupled, and total loans to households by banks tripled so

14. One cannot deny that some part of the consumption was financed by debt that was recklessly extended without scrutinizing the credibility of borrowers.

15. The term LSRP is used in the Basel II accord to represent any form of loan contract collateralized by residential properties. That includes various kinds of loan contracts such as equity loans and bullet mortgages as well as conventional long-term mortgages. We use the term LSRP to indicate the bullet mortgage explained later in detail in order to distinguish it from the conventional long-term mortgage. 
that the proportion of LSRPs in household loan portfolios rose from 58.1 percent in 2001 to 62.4 percent in 2005. The pace of LSRP growth in the booming period between 2000 and 2002 was especially spectacular, with an annual growth rate over 50 percent.

Compared to the conventional long-term mortgage contract, we can point out three distinguishing characteristics in the LSRP contract prevalent in Korea: short maturity, no amortization of principals, and low loanto-value (LTV) ratio. First, LSRP has a very short maturity structure. A typical LSRP matures in three years, and the maturity is shortened further when conditions in the credit market deteriorate. According to a survey by the Financial Supervisory Service (FSS) in 2005, 47.6 percent of LSRP have a (original) maturity no longer than three years, 21.4 percent for three to five years. On the other hand, LSRP with maturity longer than ten years occupies 25.3 percent of total LSRP, and the weight increased by 15.7 percentage points compared to the previous survey in 2003. The rapid increase is mainly attributable to the establishment of the Korea Housing Finance Corporation in 2003 in the wake of rapid increase in LSRP and subsequent rising concerns on its long-term stability. ${ }^{16}$ According to table 5.6, all countries surveyed by the Bank for International Settlements (BIS; 2006) other than Korea have long-term mortgages with maturity no shorter than ten years as the primary instrument in the housing finance market.

The second feature of LSRP in Korea is that borrowers are not required to repay the principal till maturity. Borrowers pay only interest on regular basis, and the loan is rolled over unless serious events that may harm the credibility of the borrower or collateral, such as delayed interest payment, default, and sharp decrease in housing value, happen. ${ }^{17}$ In order to deal with possible risk factors embodied in the second feature of LSRP in Korea mentioned in the preceding, LTV is set at very low level compared to a long-term mortgage with amortization. The average LTV for LSRP in Korea is currently well below 60 percent. According to table 5.6, in most of the countries with the conventional mortgage system, LTV is set at 70 percent to 80 percent when the loan contract originates.

Literature calls the type of mortgage loan dominating the housing finance market in Korea a bullet mortgage to emphasize the risk factor embodied in the loan contract (Fabozzi and Modigliani 1992). Because the principal is carried to maturity without amortization, borrowers are required to pay a very large amount of money when maturity arrives. Borrowers have three ways to deal with the arrival of maturity; refinance the debt through rollover or borrow from other lenders, repay the debt by liquidating other assets, or sell the collateralized property and settle the debt.

16. The KHFC started to sell long-term mortgage loans from March 2004.

17. Monthly interest payment is the usual arrangement. In some cases, borrowers are asked to pay a very small portion (typically less than 5 percent) of the principal as a precondition for rollover of the matured loan. 
Table 5.6 Features of mortgage contract in selected countries

\begin{tabular}{llll}
\hline Country & $\begin{array}{c}\text { Usual length } \\
\text { of contract } \\
\text { (years) }\end{array}$ & \multicolumn{1}{c}{$\begin{array}{c}\text { Estimated average } \\
\text { loan-to-value } \\
\text { ratio (new loans) }\end{array}$} & $\begin{array}{c}\% \text { of } \\
\text { owner-occupiers } \\
\text { with mortgages }\end{array}$ \\
\hline Australia & 25 & $60-70 \%$ & 45 \\
Belgium & 20 & $80-100 \%$ & 56 \\
Canada & 25 & $75-95 \%$ a & 54 \\
France & $15-20$ & $78 \%$ & 37.5 \\
Germany & $20-30$ & $80-100 \% ; 60 \%$ for Pfandbrief & n.a. \\
Italy & $5-20$ & $80 \%$ & n.a. \\
Korea & $3-20$ & $56.4 \% ;$ max $70 \%$ & n.a. \\
Japan & $20-30$ & n.a. ${ }^{\mathrm{b}}$ & n.a. \\
Luxembourg & $20-25$ & $80 \%$ & n.a. \\
Mexico & $10-15$ & $80-100 \%$ & n.a. \\
The Netherlands & 30 & $87 \% ;$ max $125 \%$ & 85 \\
Spain & $15-20$ & $70-80 \%$ & n.a. \\
Sweden & $30-45$ & $80-95 \%$ & n.a. \\
Switzerland & $15-20$ & Max $80 \% ; 65 \%$ for Pfandbrief issuance & n.a. \\
United Kingdom & 25 & $70 \%$ & 60 \\
United States & 30 & Typically about $85 \%$ & $65.1^{\text {c }}$ \\
\hline
\end{tabular}

Source: BIS (2006).

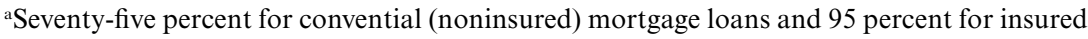
mortgage loans.

${ }^{b}$ n.a. = not available. The Government Housing Loan Corporation discloses the average loan-to-value ratio for the underlying mortgages of its mortgage backed securities (MBSs). The ratio has been approximately 70-80 percent from the first issue in March 2001 to date.

c2001 Survey of Consumer Finances, Board of Governors of the Federal Reserve System.

If the first option is available, no significant disruption would occur. A new debt contract will be signed, and the borrower is required to pay only interest without amortization of the principal until maturity. The maturity clock restarts. The second option is available for borrowers who have already accumulated enough assets to cover the amount of debt. Considering the high income-to-house price ratio in Korea, very few people qualify to choose the second option, especially among young borrowers. ${ }^{18}$ Should neither the first nor the second option be available, a borrower would be forced to sell the collateralized house to meet the repayment obligation. Under the usual circumstances, the sales receipt would be large enough to cover the repayment as long as LTV was set and maintained at an accept-

18. Average income-to-house price ratio for an urban residence is known to be around 10 in Korea. Assuming that average propensity to consume is 0.3 and average LTV is 60 percent, an average worker should save at least ten years to accumulate enough assets to cover the principal repayment. With the bullet mortgage with a maturity of three years, the mortgage contract should be rolled over three or four times for an average borrower to exercise the second option in the text. In other words, no major events that make lenders refuse rollover of matured debt should occur for a very long period of time. 
able level. The liquidation of collateral, voluntary or not, in most cases implies that the borrower confronts a stressful situation. When the stressful situation occurs at a personal level, borrowers would be able to execute the strategy. However, when it comes to a stressful situation at an economywide level, such as severe depression, they will have considerable difficulties. Under the circumstances, lenders would become very selective in granting rollover and renewing the debt contract, and a significant chunk of maturing debt would be denied renewal of contract, and most of the borrowers who are rejected in the rollover application would have to resort to liquidating the collateralized house. Enormous pressure applied to the supply side of the housing market is highly likely to result in considerable price shock or, in some cases, panic in the housing market. Disappearing liquidity, plummeting prices, and a rush to dump assets at all costs are a few examples of chaotic events we observe in a depressed-asset market. Kindleberger and Aliber (2005) documented numerous historic events when abrupt change in investors' moods or the market environment led to panic in the financial market and crisis in the economic system. With the average maturity of three years, roughly a third of total outstanding debt will mature within a year. Therefore, rapid accumulation of bullet mortgage debt has already become one of the major risk factors that might harm the stability of the financial system. Moreover, banks did not regard a borrower's income as the main variable on which the loan decision was based. In other words, as long as he or she could provide enough collateral to cover the principal, a borrower did not have difficulty obtaining a mortgage loan, even if both borrower and lender knew that the borrower did not have the ability to accumulate enough savings to repay the debt when it matured. The strategy was acceptable to both lenders and borrowers in Korea. Under a bullet mortgage contract, neither party expects the borrower to accumulate enough savings to repay the debt by the time the loan matures in two or three years. Instead, both parties expect that during the contract, the house price will increase significantly and the borrower will be able to repay the debt by using capital gain. Even if their expectation is not materialized, the borrower is easily granted a rollover of the maturing loan unless serious events occur that make it impossible to renew the loan contract, such as a delayed interest payment or a violation of the LTV condition due to a drop in the price of property offered as collateral. However, if the serious events occur on an extraordinary scale, rollover for a significant portion of matured debt will be denied, and most debtors will be forced to respond to a call for repayment by liquidating the collateral. It is highly likely that a downward spiral of the housing price will be initiated and further deterioration of the mortgage market follows, which, if not properly controlled, may lead to a disastrous collapse of the financial market and the economic system.

In a theoretical exploration on structural characteristics of the bullet 
mortgage contract, Park and Hur (2006) argue that the bullet mortgage contract is more robust to adverse income shock, but more vulnerable to adverse housing price shock than the conventional mortgage contract. Because borrowers under the conventional mortgage arrangement are required to pay interest and part of the principal, they have to set aside a larger portion of income to meet periodic repayment obligations than borrowers under the bullet mortgage. Affected by the same adverse shock to income, borrowers with a conventional mortgage will be more prone to default than borrowers with a bullet mortgage. On the other hand, borrowers with a conventional mortgage are less prone to adverse shock to the housing price than borrowers with a bullet mortgage because they are not subject to the LTV condition as long as they fulfill scheduled repayments. Under a bullet mortgage contract, borrowers are required to meet the LTV condition when the debt contracted is renewed after the maturity for the old contract arrives. Affected by a large adverse shock on the housing price, borrowers will have much difficulty meeting the LTV condition when they try to get a rollover granted by banks.

Fabozzi and Modigliani (1992) provided convincing historical evidence on the fragility of the bullet mortgage system. After the economy was seriously hit by the Great Depression, massive foreclosure of homes under the bullet mortgage contracts occurred as a result of the collapse of housing prices and failure to renew maturing mortgage contracts. The wealth effect made the recovery of private consumption very sluggish, and the economy suffered greatly from the delayed recovery. Fabozzi and Modigliani (1992) argue that the U.S. Congress enacted the National Housing Act of 1934 that offered the legal foundation for the Federal National Mortgage Association (Fannie Mae) in order to circumvent the structural problem embodied in the bullet mortgage system by encouraging the development of the long-term mortgage market.

It seems that policymakers started to notice the risk factor involved in rapid accumulation of bullet mortgage debt around 2002 and took various policy measures to help smooth rollover of maturing debts and introduce conventional mortgage instruments into the Korean housing finance market. The Korean Housing Finance Corporation (KHFC) was established in 2003 to promote a conventional mortgage market. The KHFC was assigned important instruments to accomplish the mission. First, unlike Fannie Mae or Ginnie Mae in the United States, the KHFC sells conventional long-term mortgage products to consumers thorough various financial institutions. Financial institutions are not legally involved in loan contracts, and they are simply agents employed by the KHFC. Second, the KHFC securitizes mortgage loans by issuing mortgage-backed securities.

It is too early to make a verdict on the effectiveness of government policies to reduce the risk factor in the housing finance market by promoting long-term mortgage products. However, it is very difficult to claim those 
policies showed stellar performances. Due to lack of accurate official statistics on the proportion of LSRP, we do not know how prevalent the bullet mortgage is in the Korean housing finance market. According to an FSS survey in 2005, 70.5 percent of LSRP in May 2005 were bullet mortgage loans, but the proportion declined very fast. The good news is that the proportion of LSRP with amortization doubled in two and half years. It was only 14.1 percent in 2003 but rose to 28.3 percent in May 2005. ${ }^{19}$

In spite of various policy efforts, the banking sector in Korea is still exposed to considerable risk factors stemming from structural fragility of bullet mortgage debts. It should also be mentioned that slow but steady progress toward a housing finance system with a more robust structure is clearly observed.

\section{Increase in Credit Delinquents}

In Korea, credit delinquent is the term reserved to indicate people who are in arrears for an amount larger than 0.3 million Korean Won for longer than three months and recorded at the public registry maintained by the Korea Federation of Banks. ${ }^{20}$ The information stored at the registry is shared among the member financial institutions.

The explosive increase in household debt and the subsequent deterioration in households' ability to repay resulted in a rapid increase in household arrears and credit delinquents.

According to figure 5.11, the number of credit delinquents increased significantly in 1998 and declined slightly from 1999 to 2000 . The number rose again at a rapid pace from the latter half of 2002 and continued to rise until the first quarter of 2004.

The large increase in credit delinquents in 1998 was attributable to severe depression initiated by the foreign exchange crisis at the end of 1997. Rebounding of economic conditions from the last quarter of 1998 was reflected in the slight decline in credit delinquents from 1999. The second wave of increase in registered credit delinquents started from the second half of 2002 and was closely associated with the increase in household debt between 2000 and 2002 and the sluggish economy in 2002. In the first quarter of 2003, the number of credit delinquents increased by 11.2 percent compared to the previous quarter. That was the biggest jump since the foreign exchange crisis. ${ }^{21}$ The number of credit delinquents finally exceeded 3 million and continued to reach 3.83 million in the first quarter of 2004. The term credit delinquent was officially discarded in 2005 , and the statistics on

19. It is conventional wisdom in the market that the proportion of conventional long-term mortgages has increased steadily since then.

20 . The sum is equivalent to approximately US $\$ 300$.

21. The number of credit delinquents increased by 20.4 percent in the second quarter of 2001. But the increase was due to the change in registration criteria in March 2001 and does not represent change in economic condition. 


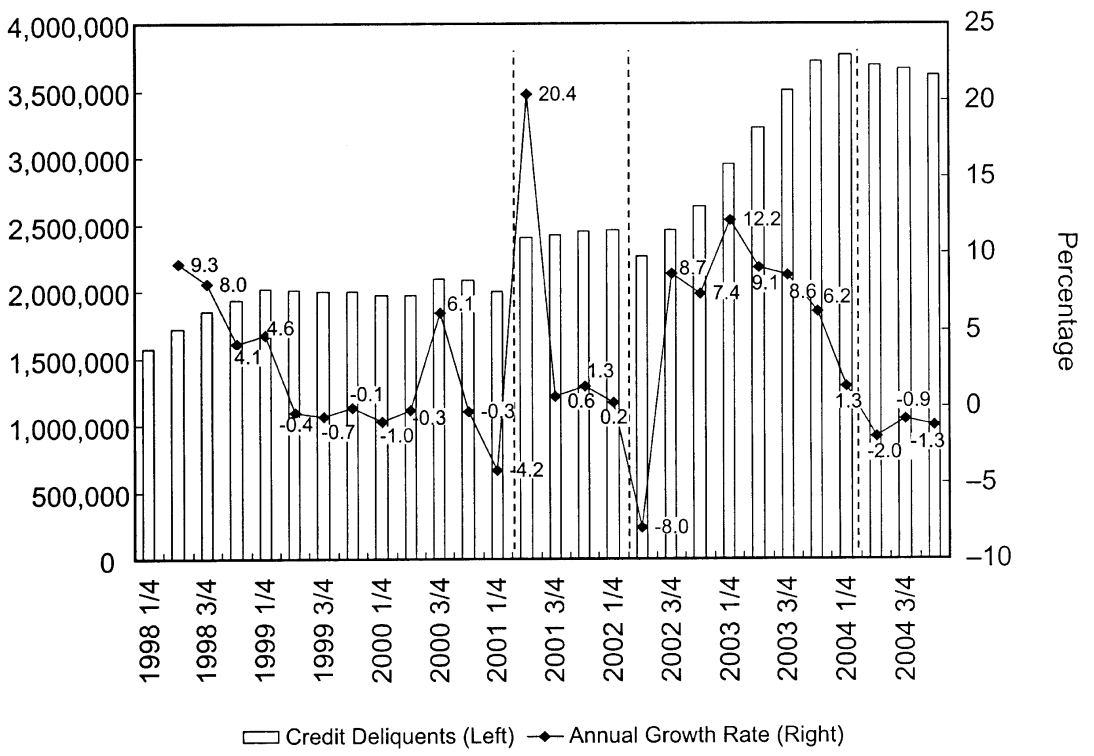

Fig. 5.11 Trend in credit delinquents

Source: Korea Federation of Banks.

Notes: The KFB tightened the criteria of registration at the second quarter of 2001. The change was reflected in a sudden jump of number of registered credit delinquents. On the other hand, the KFB lowered the criteria of registration at the first quarter of 2002. Several administrative errors were cleared in March 2004 to lead to a slight decline in the number of credit delinquents. Many were already deceased or were registered more than twice.

credit delinquents have not been announced since then. ${ }^{22}$ However, it is known that the decline that started in the second quarter of 2004 continued until the number dropped to approximately 3 million at the end of 2005. The decline was mainly due to active restructuring of nonperforming household loans rather than improvement of ability to repay the debt such as increased income or decreased debt burden.

Shin, Hahn, and Park (2003) pointed out four reasons for the rapid increase of credit delinquents after the second quarter of 2003; adverse macroeconomic conditions, serious moral hazard committed by credit card companies, inefficient allocation of credit resources due to the lack of an adequate scheme to share credit information, and improper and untimely financial regulation.

The slumping economy since the third quarter of 2000 generated adverse

22. Public registration of credit delinquents was discarded, but collection and sharing of credit information continued. The policy to register credit delinquents had been subject to severe criticism that the classification was not only an arbitrary one void of sound economic justification but became an obstacle that prevented individual financial institutions from developing a credit scoring system. 
shock on income as well as debt burden and ultimately made ability to repay deteriorate. That would result in increase of arrears in household debt and registered credit delinquents. Equation (1) based on Shin, Hahn, and Park (2003) indicates that the number of credit delinquents is positively correlated with household debt and negatively correlated with income. The result conforms with the literature reporting the empirical findings that households' ability to repay debts is associated with income, debt burden, and interest rate. ${ }^{23}$ Change in credit delinquents is regressed on lagged change in household debt and income employing the quarterly data from 1998 to 2004. An increase in household debt would result in an increase in credit delinquents a year later. Similarly, an increase in income measured by Gross National Income (GNI) would lead to a decrease in credit delinquents a year later.

$$
\begin{aligned}
\Delta \ln \mathrm{CD}_{t}= & 6.1354+\underset{(0.8153)}{0.3199 \Delta} \ln \mathrm{HD}_{t-3}+\underset{(1.5634)}{0.6005 \Delta} \ln \mathrm{HD}_{t-4} \\
& -\underset{(-0.7764)}{0.3232 \Delta} \ln \mathrm{GNI}_{t-1}-\underset{(-1.5039)}{0.4971 \Delta} \ln \mathrm{GNI}_{t-2} \\
& -\underset{(-0.9082)}{0.2116 \Delta} \ln \mathrm{GNI}_{t-3}-\underset{(-1.8634)}{0.4318 \Delta} \ln \mathrm{GNI}_{t-4} \\
& +\underset{(2.3368)}{8_{(234)}} D_{01 / 2} \\
R^{2} & =0.5034 \quad \text { number of observations }=28
\end{aligned}
$$

In equation (1), $D_{01 / 2}$ indicates the dummy for change in registration criteria occurred in the second quarter of 2001, and $t$-values are in parentheses under the estimates.

Explosive growth of credit card loans in 2000 and 2001 and the subsequent increase in the default rate is another important factor that sparked an increase of credit delinquents. Deregulation of the credit card industry in 1999 triggered a throat-cutting competition to expand market share among credit card companies. The competition was a blind race to take the top position in size. Many borrowers with very high credit risk who would have been refused loans were allowed to access the credit market without proper credit evaluation. Owned by banks or large conglomerates, credit card companies underevaluated the possibility of their failure and charged into the competition with no prudence. They believed that they were too big to fail and the government would not be able to watch them get into trouble. That was a reckless moral hazard committed by credit card companies. Moreover, the majority of bonds issued by credit card companies to finance credit card loans were possessed by banks and money market funds that are generally regarded to be linked to system risk. That also fueled the belief that the government would not allow credit card companies to get into difficulty. Credit cards were issued recklessly without proper

23. For an excellent survey on the topic, see CBO (2000). 
checks on credit risk, and the limits on cash advance services were raised frequently even if the borrower had already held a significant outstanding balance to repay.

As we have already seen in figure 5.6, increase in credit card debt during the boom in 2000 and 2001 was led by a cash advance service that embodied much higher credit risk than other forms of services credit cards provide. Confronting mounting arrears and accumulation of distress assets, the financial regulator took a decisive measure to stop the rapid expansion of credit card debts and prevent further deterioration of the situation. ${ }^{24}$

The growing concern about the viability of credit card companies and the sudden turning of policy stance resulted in a violent crash ending in the fourth quarter of 2002. Already having huge difficulty in paying monthly bills, a significant portion of credit card debtors had managed to escape falling into arrears by financing a new debt from other credit card companies or the usurious private loan market. Sudden strengthening of regulatory measures and subsequent tightening of credit risk management by credit card companies resulted in a massive increase in arrears. That could explain a lot of the steep increase of credit delinquents in 2003.

In order to see the role played by credit card companies in growing credit delinquents, we decompose the credit delinquents according to the financial institutions that reported them overdue, satisfying the registration criteria. Figure 5.12 illustrates the change in credit delinquents registered by a single type of financial institution. It is obvious that credit card companies played the most significant role in the increase of credit delinquents both in the second quarter of 2001 and in the second half of 2002.

We can draw the same conclusion from figure 5.13 that reports the changes in the number of credit delinquents registered by more than one kind of financial institution. Among the increase in the registered by multiple categories of financial institutions, nearly 90 percent were involved with credit cards in 2002 and 95 percent in 2003.

Lack of a well-functioning credit information system is pointed out as another major contributing factor to the aggravation of the problem. Roughly speaking, the credit information system consists of a credit reporting system that collects and distributes credit information among financial institutions and a credit evaluation system of individual financial institutions that evaluates the creditworthiness of individual borrowers, such as a credit scoring system (CSS) and behavior scoring system (BSS).

The current form of credit reporting system was established in Korea in 1955 when the Bank Supervisory Office introduced a compulsory reporting system that obliged all participating financial institutions to report delinquent credit information satisfying criteria set by agreement among

24. We will discuss the development of the credit card crisis in 2003 in the next section. 


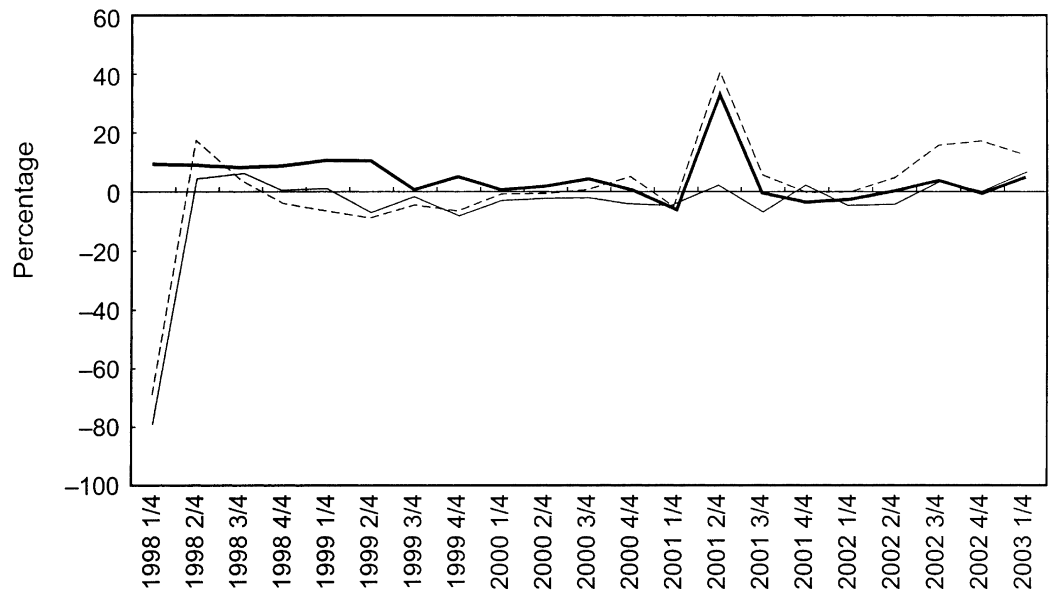

Banks

Credit Card Companies

Others

Fig. 5.12 Change in credit delinquents by financial institutions (FIs): Single registration

Source: Korea Federation of Banks.

Note: Others include insurance companies, mutual savings banks, and mutual cooperatives.

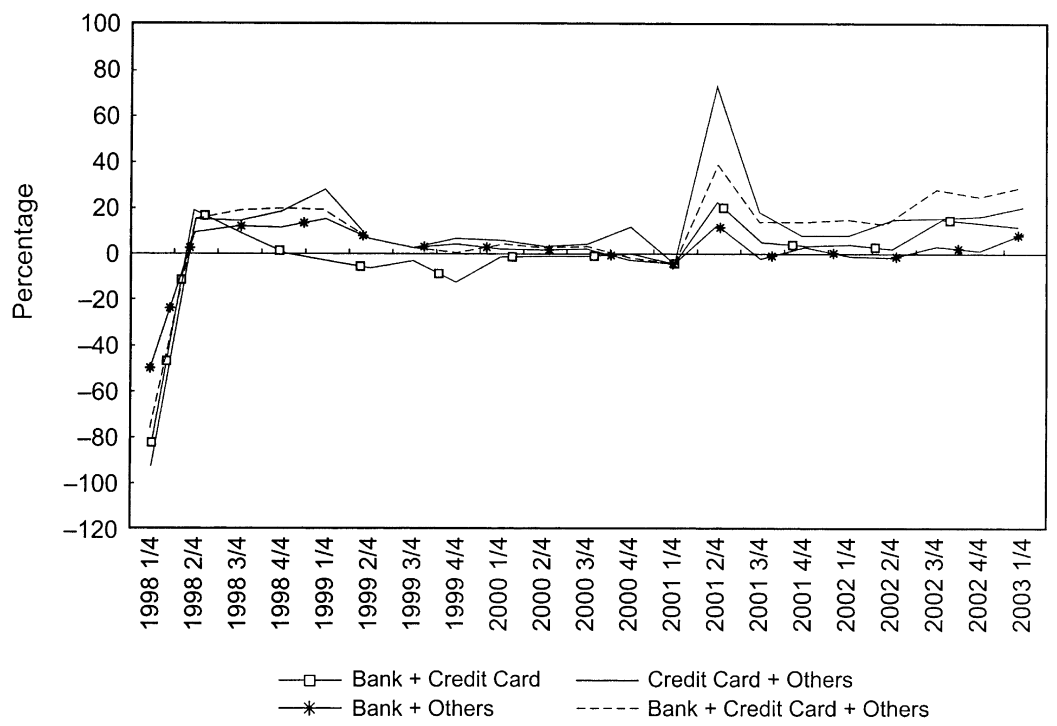

Fig. 5.13 Change in credit delinquents by financial institutions (FIs): Multiple registrations

Source: Korea Federation of Banks.

Note: Others include insurance companies, mutual savings banks, and mutual cooperatives. 
participating financial institutions. ${ }^{25}$ Under the Use and Protection of Credit Information Act (UPCIA) enacted in 1995, the Korea Federation of Banks was appointed as the agent of the Banking Supervisory Office to maintain the public registry empowered by the law. ${ }^{26}$ The credit information gathered by the public registry and shared among participating financial institutions consisted mainly of negative information such as loan delinquency, default, and fraud. Positive information maintained by the registry was limited to outstanding loan balance and number of credit cards held. Moreover, it was not until 2001 that the limited range of positive information began to be collected by the registry. It is a well-known proposition that the use of credit information limited to negative information results in inefficient allocation of credit resources by lowering the accuracy of the credit evaluation system. ${ }^{27}$ Therefore, the lack of adequate credit information must have, at least in part, contributed to inefficient allocation of credit resources and ultimately to an increase in credit delinquents. However, the practice to evaluate credit risk of individual borrowers was a more important reason for the serious development of the problem. According to Shin and Park (2006), it was not until 2003 that banks seriously regarded the credit scoring system as an integral part of decision making on consumer loans ${ }^{28}$ Moreover, credit card companies also did not have a workable credit scoring system until 2003 when the credit card crisis hit the industry very hard. In sum, we can conclude that the startling growth of household debt between 2000 and 2002 was not issued based on sound practice of evaluating borrowers' credit risk, and a huge jump in credit delinquents in 2001 and 2003 was a somewhat predictable event.

Last, we can point out the role of untimely and improper regulatory responses in the deterioration of conditions in the market. The mistakes committed by the regulatory authority during the development of events become more conspicuous when we examine the series of policy measures taken in response to development in the credit card market since 2002. We

25. The integrated body of financial regulators, the Financial Supervisory Commission (FSC) and the Financial Supervisory Service, was established after the foreign exchange crisis. Before the FSC was established in 1998, there were three main separate financial regulators, the Bank Supervisory Office in the Bank of Korea, the Securities Supervisory Office, and the Insurance Supervisory Office.

26. The Korea Federation of Banks had already performed as the de facto public registry of credit information since early 1980s through the authorization of the Bank Supervisory Office. However, the authorization was not based on the legal mandate but on the convenience of the supervisor.

27. See Barron and Staten (2003) for a detailed discussion of the value of positive information on the performance of the credit scoring system.

28. The first credit scoring system in the Korean banking sector was introduced by Hana Bank in 1996. Other banks followed in introducing a credit scoring system in the late 1990s. However, the traditional evaluation system utilizing a score card had been the primary tool used in loan decisions. The credit scoring system was not regarded as the integral part of the process and was used as a supplementary device. 
will present a detailed discussion on the policy responses to credit card crisis in the next section.

\subsection{Credit Card Crisis: Policy Responses and Evaluation}

\subsubsection{Development of the Credit Card Crisis}

Even though the credit card was first introduced to Korea in 1979, the appearance of the credit card as a major financial instrument in the consumer credit market should wait about twenty more years as we discussed in previous sections.

In addition to the spectacular growth of credit card debt since 2000 we discussed in the previous sections, one can quote the following statistics in order to give more hints on how fast credit card usage penetrated the Korean economy since the foreign exchange crisis. The number of merchants accepting credit cards was less than one million in 1992, and it increased seventeen fold in just ten years to mark 17 million participating merchants in 2003. On the other hand, the average number of credit cards an economically active person in Korea possesses also increased very fast, from one in 1993, to two in 1998, and to a peak of 4.6 in 2002. The use of the credit card has become so common that about a half of total private consumption expenditure has been intermediated by the credit card since 2002. The comparable figure was only 15.5 percent in 1999 .

As an almost inevitable consequence of fast credit expansion, the average quality of a loan portfolio started to drop. The overdue loan rate was already crawling up in the second half of 2001 when few raised questions about possible risk factors behind the fast loan growth. The overdue loan rate for debt by credit card companies increased very fast, reaching 10.9 percent at the end of 2002. It seemed that the steep increase in the overdue rate was temporarily halted during the first half of 2003. However, the official statistics on the overdue loan rate was quite misleading because confronted with mounting overdue loans, credit card companies tried to window-dress the quality of their loan portfolios by replacing overdue loans with additional credit to debtors in serious arrears. Official statistics did not include the overdue loans once they were replaced by new loans. ${ }^{29}$ It is natural that we expect a very high overdue rate on that type of loan. Therefore, the temporary halt in the increase of the overdue loan rate in the first half of 2003 was the result of strategic behavior by credit card companies to disguise the seriousness of the problem. One can confirm from figure 5.14 that the overdue rate with replacement loans could be twice as high as the overdue rate without them. Hence, we can conclude that the

29. The Financial Supervisory Service changed the stance on the official statistics only after they faced severe criticism against the practice in 2004. 


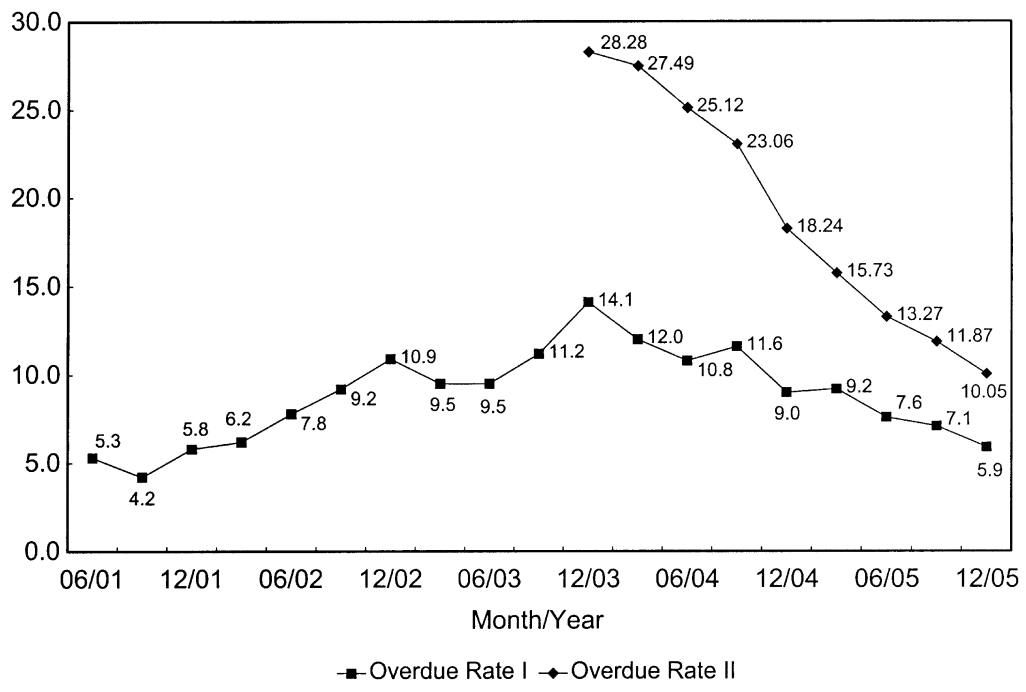

Fig. 5.14 Overdue rate of credit card loans

Source: Financial Supervisory Service.

Notes: Overdue rate I indicates the overdue loan rate excluding replacement loans. Overdue rate II indicates the overdue loan rate including replacement loans.

overdue loan rate increased steadily at least until the end of 2003. Additionally, we also find in figure 5.15 that both profitability and quality of loan portfolios showed a significant decline from the second half of 2002.

The pressure was building up in the credit card industry as the overdue loans accumulated and the quality of loan portfolios deteriorated. The momentum that brought in the turbulent crisis in the credit card industry was offered by exogenous events outside the credit card market. The accounting fraud committed by SK Global Corporation was uncovered in March 2003, which sparked the spread of a pessimistic perspective across financial market. ${ }^{30}$ The growing concern about the strength of the financial market hit the weakest spot at the time. The liquidity of the bonds issued by credit card companies suddenly evaporated.

The most conspicuous symptom of liquidity evaporation is illustrated in figure 5.16, which depicts the change in outstanding stock of money market funds and short-term funds around the revelation of the accounting fraud by SK Global in March 2003. Those funds carried portfolios focusing on bonds issued by credit card companies. Investors rushed to secure

30. The amount of accounting fraud committed by SK Global was 1.56 trillion Korean Won. Virtually all imaginable kinds of accounting irregularities were utilized to camouflage the deterioration of the balance sheet. Liability was undervalued, while asset was grossly overvalued. 


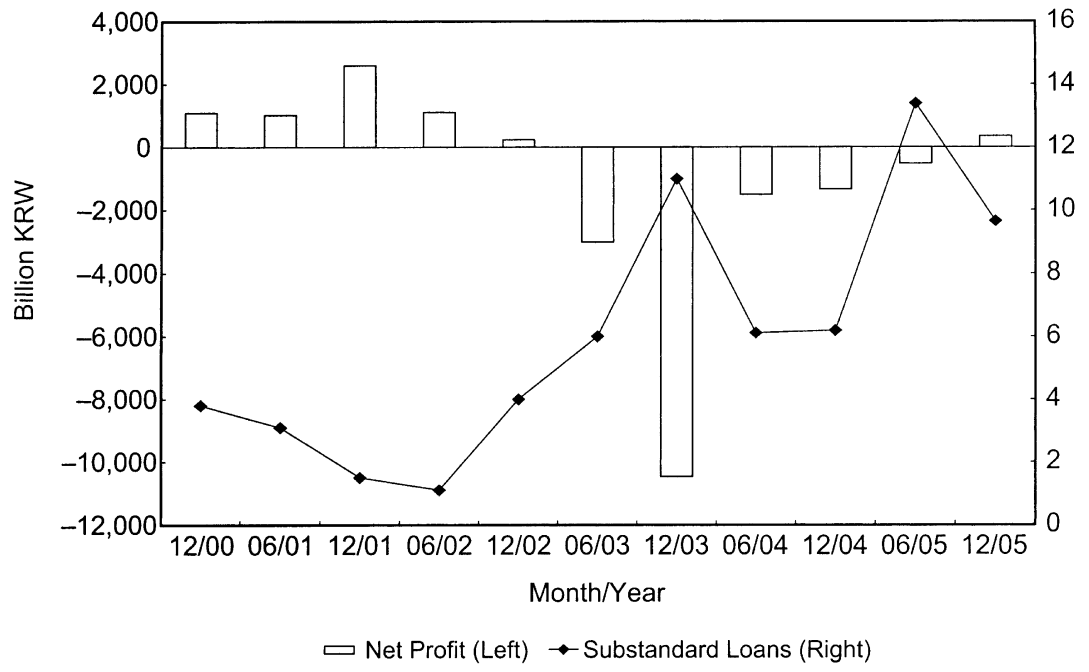

Fig. 5.15 Net profit and quality of loan portfolios of credit card companies Source: Financial Supervisory Service.

Note: Substandard loans indicate the proportion of loans classified as substandard or below.

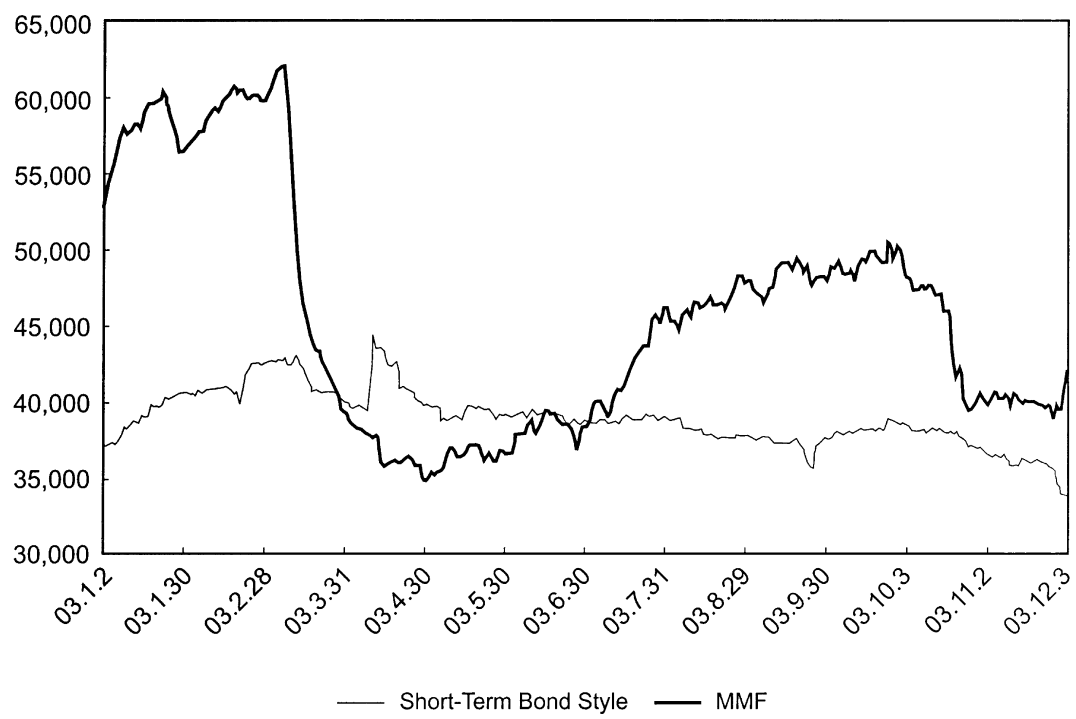

Fig. 5.16 Outstanding stock of money market fund (MMF) and short-term bond fund

Source: Korea Association of Asset Management Corporations. 
their investment on those funds, and fund managers were forced to dump credit card bonds to meet the call for repurchasing from investors. Confronted with a severe liquidity crisis, credit card companies were not able to secure enough capital to meet the repayment requirement for the maturing bonds they had issued.

Alarmed by the possibility of contagion of the crisis to other sectors in the financial market, especially the banking sector, due to complex transactions among financial institutions, the Korean government promptly intervened and mediated debt rescheduling negotiations between credit card companies and lending financial institutions to avert a catastrophic collapse of the financial market. Credit card companies issued various debt instruments such as commercial paper, corporate bonds, and asset-backed securities. The total debt of credit card companies was 17.6 trillion KRW at the end of 2002. Investment trust companies that managed various kinds of funds were the biggest lender, with an outstanding balance of 25.5 trillion KRW. Banks followed at a close distance by lending 21.7 trillion KRW to credit card companies. Insurance companies, security companies, and pension funds also extended a significant amount credit to credit card companies (see table 5.7).

Considering the size of debt held by banks and insurance companies that are widely regarded to be related to system risk, some argue that the government intervention was well warranted.

Agreement between credit card companies and lending financial institutions was reached in April 2003. Credit card companies promised to strengthen their financial structure by injecting more capital, and lending financial institutions agreed to delay the redemption of matured bonds issued by credit card companies. The financial market regained a sense of stability, and credit card companies were able to secure liquidity by selling newly issued bonds and structured securities that were backed by portfolios of credit card loans.

However, the market had not retracted the doubt on the viability of credit card companies and kept a watchful eye on the fulfillment of promised injection of additional capital to strengthen the financial structure. The largest credit card company, LG Card, had become the main target in the bond market. The overdue rate on LG Card's loan portfolios stayed at very high level, and the proportion of nonperforming loans rose very fast

Table 5.7

Lenders of credit card companies by financial institution (trillion KRW)

\begin{tabular}{ccccccc}
\hline & $\begin{array}{c}\text { Investment } \\
\text { trust }\end{array}$ & Banks & $\begin{array}{c}\text { Insurance } \\
\text { company }\end{array}$ & $\begin{array}{c}\text { Security } \\
\text { company }\end{array}$ & $\begin{array}{c}\text { Pension } \\
\text { fund }\end{array}$ & Total \\
\hline Amount & 25.5 & 21.7 & 12.7 & 2.1 & 8.0 & 89.4 \\
\hline
\end{tabular}

Note: The table illustrates the position at the end of 2003. 
even after the agreement in April between credit card companies and financial institutions that provided credit to them. Moreover, the fulfillment of the capital expansion plan promised by the group of large shareholders consisting of the family members controlling LG Group, then the third largest conglomerate in Korea, was delayed. When the news that the group of large shareholders had sold their shares in a discrete manner hit the market, it suddenly became impossible to trade the bonds issued by LG Card, and the company again faced severe difficulty in securing liquidity. The company was overtaken by lending financial institutions led by the Korea Development Bank, and a series of negotiations among creditors to devise a plan to bail out the company came into fruit finally in December 2003.

\subsubsection{Regulatory Failures}

The first regulatory misstep was committed in 1999 when the ceiling on the cash advance service was removed as a part of the deregulation and liberalization of the financial market. It is very hard to question the legitimacy of the deregulation measure in that setting the limit of the cash advance service should be left to the private contract negotiated between credit card company and customer. However, it is also true that in the absence of an adequate credit evaluation system, the uniform ceiling on the maximum amount of cash advance services played an important role in checking the uncontrollable increase in cash advance services and keeping the soundness of loan portfolios held by credit card companies. Before the deregulation measure was taken, the cash advance service was limited to 700,000 KRW, and that was not linked to creditworthiness of individual borrowers. Credit card companies did not have either the will or the resources to be equipped with a credit evaluation system. Free from harness, credit card companies plunged into brutal competition to increase market shares. Along with the removal of the ceiling on cash advance services, credit card companies made a decision not to share credit information about customers' available credit amounts and card issuances that made unfettered increase in credit card debt possible. As an inevitable result of the ill-advised deregulation measure, credit card debt accumulated in an unprecedented pace in 2001 and 2002, and a fast increase in registered credit delinquents in 2003 followed.

The second regulatory misstep was committed during the boom between 2000 and 2002. Despite increasing risks due to fast growing credit card debts, the financial regulator did not fully understand the fundamental nature of the problem. During the booming era, the credit card industry was regarded as a highly profitable sector, and many financial institutions were willing to provide credit to credit card companies by buying various debt instruments issued by them. Table 5.8 reports the amount of credit financed by various debt instruments. The outstanding stock of debt instruments issued by credit card companies increased fivefold from 1999 to 
Table 5.8

Financing by various debt instruments (billion KRW)

\begin{tabular}{lrrrr}
\hline & 1999 & 2000 & 2001 & 2002 \\
\hline Commercial paper & 4,084 & 9,649 & 11,324 & 20,888 \\
Bonds & 10,850 & 16,731 & 18,665 & 29,612 \\
Asset backed security & & 4,476 & 26,712 & 33,535 \\
Others & 2,905 & 2,666 & 4,445 & 3,632 \\
Total & 17,839 & 33,264 & 61,146 & 87,666 \\
\hline
\end{tabular}

2002, and most of the debts were taken by banks and investment trust companies in which banks had invested a significant portion of funds under management as shown in table 5.7.

The high profitability of credit card companies that attracted huge amount of credit into the sector was primarily based on the high interest rate charged on overdue loans. Borrowers were able to pay the high interest charged on overdue loans as long as they were allowed access to other credit provisions. In other words, debtors already in arrears were able to borrow from another credit card company to pay overdue loans. It looked as if the high profitability of credit card companies would last forever. However, that was the correct presumption only if borrowers could find another credit card company to grant credit that would be used to pay the existing overdue loan. That, however, is a form of financial pyramid that cannot be sustained and could be busted anytime.

Knowing the fragility of the scheme and observing the fast inflow of huge credit into credit card companies, the financial regulator should have intervened promptly. They should have blocked the inflow of credit by tightening supervisory activities on banks and investment trust companies. The financial regulator had the legitimate power to ask those financial institutions to stop providing further credit from the perspective of prudential regulation.

The third misstep was committed in 2002 when the financial regulator took several measures to curb rapid credit expansion by credit card companies. Giving up the laissez-faire attitude toward the credit card industry, the financial regulator suddenly changed the policy stance and imposed several very strong policy restrictions on them. The objective of the policies was to restore stability in the credit card market and to avoid realization of system risk. More specifically, the proportion of cash advance services out of total financial activities should be maintained under 50 percent, and prompt corrective action for failing credit card companies was introduced. Most notably, the provision standard for bad debts was strengthened. The new standard was even higher than the one required for banks, and credit card companies suffered loss of confidence due to a de- 
teriorated position in income statements. The position in income statements declined simply because credit card companies were required to set aside more resources to meet the strengthened provision standard.

No one can raise a question to the necessity of the policy measures to restore stability of the market. But the timing and strength of regulatory interventions invited strong criticism from both the market and the expert commentators. Already in deep trouble in repaying monthly bills, a significant portion of credit card debtors managed to avoid falling into arrears by financing a new debt from other credit card companies or the usurious private loan market. Sudden strengthening of regulatory measures and subsequent tightening of credit risk management by credit card companies resulted in a rapid increase in arrears and a decrease in credit card debts. Consequently, the number of credit delinquents recorded at the public registry soared by more than 50 percent in a year. Many observers claim that the regulatory authority could have been able to avoid such a violent crash landing with a more cautious choice of timing and intensity of policy execution.

\section{References}

Bank for International Settlements (BIS). 2006. Housing finance in the global financial market. CGFS Paper no. 26. Basel, Switzerland: BIS, Committee on the Global Financial System.

Barron, J., and M. Staten. 2003. The value of comprehensive reports. In Credit reporting systems and the international economy, ed. M. Miller. Cambridge, MA: MIT Press.

Bertola, G., R. Disney, and C. Grant. 2006. The economics of consumer credit. Cambridge, MA: MIT Press.

Congressional Budget Office. 2000. Personal bankruptcy: A literature review. CBO Paper. Washington, DC: Congressional Budget Office.

Crook, J. 2001. The demand for household debt in the USA: Evidence from the 1995 Survey of Consumer Finance. Applied Financial Economics 11:82-91.

. 2006. Household debt demand and supply: Cross-country comparison. In The economics of consumer credit, ed. G. Bertola, R. Disney, and C. Grant, 6392. Cambridge, MA: MIT Press.

Fabozzi, F., and F. Modigliani. 1992. Mortgage and mortgage-backed securities markets. Boston, MA: Harvard Business School Press.

Honoré, B. 1992. Trimmed LAD and least squares estimation of trucated and censored regression models with fixed effects. Econometrica 60:533-63.

Kim, J. 1995. Liquidity constraints and consumption expenditure: A comparative analysis for Korea, Japan, and the United States. KDI Journal of Economic Policy 17:63-96.

Kindleberger, C., and R. M. Aliber. 2005. Manias, panics, and crashes: A history of financial crises. 5th ed. New York: Wiley.

Park, C., and S. Hur. 2006. Impacts of the new Basel Accord on housing finance market in Korea. Korea Development Institute. Mimeograph. 
Shin, I., C. Hahn, and C. Park. 2003. The causes of increase in credit delinquents and policy tasks (in Korean). KDI Policy Report. Seoul: Korea Development Institute.

Shin, I., and C. Park. 2006. Credit information system in Korea: Current condition and policy priorities (in Korean). KDI Policy Report. Seoul: Korea Development Institute.

\section{Comment Winston T. H. Koh}

The chapter examines the events surrounding the rapid expansion of household debt in South Korea since the foreign exchange crisis that Korea suffered in 1997, which occurred as part of the Asian Financial Crisis. A specific focus of the chapter is to investigate the developments in the housing loan market and the credit card crisis in 2003, and the government response to address the issues in both the housing loan market and the credit card industry. The chapter argues that the crisis stems from regulatory failure, and with timely and proper regulatory actions, much of the difficulties that occurred in the credit card market would have been alleviated or averted.

I will make two general comments about the chapter, before going into the specific comments. Firstly, in light of the intersecting sets of issues discussed in the chapter, it would be useful to provide, as a backdrop to the analysis, a brief discussion of the state of the South Korean economy since 1997 , in terms of rate of gross domestic product (GDP) growth, foreign investment inflow, current account deficit, and so on in order that the reader can better appreciate the forces driving the economy and understand the impetus for the business strategies of the banks and credit card companies and the government's responses. In particular, it would be useful to find out if there were certain macroeconomic conditions that had prevented the authorities from taking certain preventive or corrective actions to address the developments in the credit markets.

Second, to the extent that data are available, it would be interesting to analyze the data by age of household head as well as by income/assets to gain a fuller picture. Table 5.1 and 5.2 look at household debt by age and income/asset holdings, respectively. It would be interesting to analyze the data by age of household head as well as by income/assets, if the data are available.

Winston T. H. Koh is an associate professor of economics and associate dean of the School of Economics at Singapore Management University. 